\title{
Article
}

\section{The Molecular Aspects of Disturbed Platelet Activation through ADP/P2Y 12 Pathway in Multiple Sclerosis}

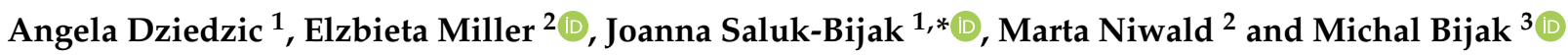 \\ 1 Department of General Biochemistry, Faculty of Biology and Environmental Protection, University of Lodz, \\ Pomorska 141/143, 90-236 Lodz, Poland; angela.dziedzic@edu.uni.lodz.pl \\ 2 Department of Neurological Rehabilitation, Medical University of Lodz, Milionowa 14, 93-113 Lodz, Poland; \\ elzbieta.dorota.miller@umed.lodz.pl (E.M.); marta.niwald@umed.lodz.pl (M.N.) \\ 3 Biohazard Prevention Centre, Faculty of Biology and Environmental Protection, University of Lodz, \\ Pomorska 141/143, 90-236 Lodz, Poland; michal.bijak@biol.uni.lodz.pl \\ * Correspondence: joanna.saluk@biol.uni.lodz.pl; Tel.: +48-42-635-43-36
}

\section{check for}

updates

Citation: Dziedzic, A.; Miller, E.; Saluk-Bijak, J.; Niwald, M.; Bijak, M. The Molecular Aspects of Disturbed Platelet Activation through ADP/P2Y 12 Pathway in Multiple Sclerosis. Int. J. Mol. Sci. 2021, 22 , 6572. https://doi.org/10.3390/ ijms22126572

Academic Editors: Valeria Gasperi, Isabella Savini and Maria Valeria Catani

Received: 18 May 2021

Accepted: 16 June 2021

Published: 18 June 2021

Publisher's Note: MDPI stays neutral with regard to jurisdictional claims in published maps and institutional affiliations.

Copyright: (c) 2021 by the authors. Licensee MDPI, Basel, Switzerland. This article is an open access article distributed under the terms and conditions of the Creative Commons Attribution (CC BY) license (https:/ / creativecommons.org/licenses/by/ $4.0 /)$.
Abstract: Epidemiological studies confirm a high risk of ischemic events in secondary-progressive multiple sclerosis (SP MS) patients, directly associated with an increased level of pro-thrombotic activity of platelets. Our work aimed to verify potential molecular abnormalities of the platelet P2 $\mathrm{Y}_{12}$ receptor expression and functionality as a cause of an increased risk of thromboembolism observed in the course of MS. We have demonstrated an enhanced platelet reactivity in response to adenosine diphosphate (ADP) in SP MS relative to controls. We have also shown an increased mRNA expression for the P2RY12 gene in both platelets and megakaryocytes, as well as enhanced density of these receptors on the platelet surface. We postulate that one of the reasons for the elevated risk of ischemic events observed in MS may be a genetically or phenotypically reinforced expression of the platelet P2 $Y_{12}$ receptor. In order to analyze the effect of the PAR1 (protease activated receptor type 1) signaling pathway on the expression level of $\mathrm{P}_{2} \mathrm{Y}_{12}$, we also analyzed the correlation parameters between P2 $\mathrm{Y}_{12}$ expression and the markers of platelet activation in MS induced by selective PAR1 agonist (thrombin receptor activating peptide-6, TRAP-6). Identifying the molecular base responsible for the enlarged pro-thrombotic activity of platelets in SP MS could contribute to the implementation of prevention and targeted treatment, reducing the development of cardiovascular disorders in the course of the disease.

Keywords: $\mathrm{P}_{2} \mathrm{Y}_{12}$ receptor; adenosine diphosphate; blood platelets; multiple sclerosis

\section{Introduction}

Blood platelets belong to principal hemostatic cells, but besides participating in thrombotic mechanisms, they also play a key role in inflammation, including neuroinflammatory events. Platelets are involved in the pathophysiology of central nervous system (CNS) disorders, for example the pathogenesis of multiple sclerosis (MS), although their role in this pathology still needs to be clarified [1]. The same molecular mechanisms that underlie the hemostatic function of platelets also facilitate the participation of these cells in other physiological and pathological processes due to the cooperation with immunologically competent cells in inflammatory and immune responses [2]. As mentioned, blood platelets serve a critical function in hemostasis, but their small size keeps them in the external blood stream close to the vessel wall and allows them to quickly reach the site of endothelial inflammatory damage, while their enormous reactivity in response to various stimuli make them an important element of the immune response [3]. Platelets, in the physiological condition, are in a resting state in circulation, but become activated due to the action of soluble platelet agonists such as thrombin, ADP, thromboxane A2 (TXA2), and others. The expression of multiple membrane receptors determines the dynamic process of platelet activation. Numerous active molecules induce signal transduction via their respective receptors and 
intermediate signaling events [4]. The presence of constitutive receptors involves multiple feedback loops and induces activation-dependent receptors, which, like P-selectin, support cross-talk between platelets and endothelial and immune cells [5]. Cell-cell interactions provide crucial mechanisms used by platelets to link thrombosis, inflammation, and related processes, such as diapedesis and infiltration of leukocyte into the affected vessel [6-8]. The direct interaction of platelets with endothelium and inflammatory cells using surface receptors promotes leukocyte recruitment to the inflamed tissue [9]. The pathomechanism of MS involves a disruption of the blood-brain barrier (BBB), which is induced by the enormous influx of inflammatory cells. Their recruitment, and in consequence, a pro-inflammatory stimulation of microglial cells, results in the destruction of the myelin sheath, accelerating the formation of demyelinating lesions [10].

MS is a chronic, neurodegenerative, immune-mediated disease, which is considered a complex neurological disorder with diverse pathophysiological mechanism and variable clinical courses, which are not equally represented in the population of patients but may selectively predominate in individuals. There is a large number of various pathogenic effectors, which can be responsible for the neuronal/axonal degeneration in MS [11]. Therefore, MS is unpredictable as well as difficult to treat. The currently used therapies are mainly based on eliminating adverse symptoms accompanying the course of the disease [12].

Determination of molecular mechanisms of increased platelet activity in MS may be beneficial for the improvement of applied treatments. Many reports have proven that blood platelets are chronically overactivated in neurodegenerative diseases, including MS [13-16]. The vast majority of data on the mechanisms of the platelet pathophysiology of MS is based on research conducted among patients in the first stage of the disease, with a relapsingremitting MS (RR MS) [16-18]. Ultimately, after 10-15 years of disease duration, RR MS in approximately $85 \%$ of cases converts into a secondary-progressive (SP MS) disease in which patients suffer irreversible disability progression, without a remission [19]. In contrast to other studies, for many years, our research has focused on disturbances in the homeostatic function of blood platelets exclusively in the SP MS, which is characterized by a particularly high risk of cardiovascular disorders compared to other MS types [20,21]. Despite the fact that SP MS is mainly dominated by neurodegeneration, it is also characterized by an extensive inflammatory process. Many of MS research mainly focuses only on the active phase of the disease (RRMS) and there is still lack of research in the group of patients with progressive phase of MS [22]. Our previous studies not only indicated an excessive intravascular activation of these cells, but also their hyper-responsiveness to the number of physiological agonists in SP MS [23,24]. When considering the pro-thrombotic and pro-inflammatory potential of platelets, it may be highly valuable to recognize the factors potentially predisposing them to overactivation in MS. Our research is focused on seeking the cause of the heightened pro-thrombotic potential of blood in SP MS, as a consequence of molecular changes within blood platelets and/or their precursor cells-megakaryocytes. Shankar et al. have demonstrated that the $\mathrm{P}_{2} \mathrm{Y}_{12}$ receptor-mediated signaling pathway plays an important role in arachidonic acid release and thromboxane A2 (TXA2) generation in response to thrombin receptor activation. Our recently published work indicates the molecular aspects of an increased PAR1-dependent activation pathway, which may have thromboembolic consequences in the course of MS [25].

The PAR1 signaling pathway is largely mutually dependent on the induction of the $\mathrm{P}_{2} \mathrm{Y}_{12} / \mathrm{Gi}$ pathway by ADP [26]. Induction of PAR1 receptor is primarily responsible for the raised expression of $\mathrm{P}_{2} \mathrm{Y}_{12}$ mRNA, as well as a total $\mathrm{P}_{2} \mathrm{Y}_{12}$ cellular protein and its cell surface expression due to the exposure to thrombin [27]. ADP is one of the major platelet agonists. ADP acting synergistically with thrombin are fundamental agents for the formation of a platelet plug that leads to the occlusion of a blood vessel [28]. Therefore, dual antiplatelet therapy based on acetylsalicylic acid and clopidogrel (thromboxane A2 (TXA2)- and $\mathrm{P}_{2} \mathrm{Y}_{12}$-inhibitor, respectively) is the primary treatment of artery ischemic events [29]. Acetylsalicylic acid (ASA) participates in the arachidonic acid cascade initiated 
by secondary messengers generated during the activation of G-protein-coupled receptors such as PAR and P2 $\mathrm{Y}_{12}$ [30], and acts as an inhibitor of the cyclooxygenase 1 and 2 (COX-1 and COX-2), lipoxygenase, and cytochrome P450 monooxygenase (CYP450) pathways [31]. COX-1 is constitutively expressed in blood platelets, as well as in neurons and microglial cells, and plays a key role in the conversion of arachidonic acid to essential cell-signaling eicosanoids, while COX-2 is involved in the later stages of an inflammatory reaction when it starts the development of the immune response [32]. The antiplatelet mechanism of ASA activity is based on acetylation of serine at position 529 in COX-1 and 516 in COX-2 leading to inhibition of TXA2 synthesis in the platelets [33]. In addition, ASA affects the activation and aggregation of platelets, and limits platelet degranulation and the release of growth factors and cytokines [34]. Clinical studies have proven that the pharmacologic blockade of platelet $\mathrm{P}_{2} \mathrm{Y}_{12}$ receptor with the selective antagonist, such as clopidogrel or ticagrelor, as well as genetic deletion of $\mathrm{P}_{2} \mathrm{Y}_{12}$, significantly diminished the risk of cardiovascular incidents, indicating the major role of the ADP/P2 $\mathrm{Y}_{12}$ pathway in ischemic events [35-37].

The aim of this work has been to verify the potential molecular abnormalities of platelet $\mathrm{P}_{2} \mathrm{Y}_{12}$, which may be a contributing factor to the well-established increased risk of ischemic events in SP MS. We hypothesized that the increased ADP-dependent platelet reactivity in SP MS is due to an impaired expression or functionality of the $\mathrm{P}_{2} \mathrm{Y}_{12}$ receptor. For this purpose, we evaluated the ability of blood platelets to activate in response to the ADP action in whole blood using the double-labelled flow cytometry method. P2Y 12 functionality in SP MS was determined by the basic markers of platelet activation (the level of platelet-platelet aggregates (PAGs), platelet-leukocyte aggregates (PLAs), plateletderived microparticles (PMPs), and surface expression of P-selectin), and most importantly, we measured the platelet reactivity index (PRI), which is the value obtained by the ADPdependent VASP (vasodilator-stimulated phosphoprotein) phosphorylation evaluation assay. We have also visually presented the expression level of the platelet P2 $\mathrm{Y}_{12}$ surface receptor after ADP stimulation.

Moreover, comparative analysis was performed to evaluate the expression of the $P 2 R Y 12$ gene and the concentration of the $\mathrm{P}_{2} \mathrm{Y}_{12}$ receptor molecules in blood platelets and megakaryocytes, which are platelet precursor cells. The difference in the surface density of the $\mathrm{P}_{2} \mathrm{Y}_{12}$ receptor after ADP stimulation between SP MS and control platelets was also illustrated by the flow cytometric method. Focusing on the molecular aspects of enhanced platelet activation through the ADP/P2 $\mathrm{Y}_{12}$ pathway, in this paper we also analyze the influence of the PAR1-dependent pathway on P2 $\mathrm{Y}_{12}$ signaling. The mRNA expression level for P2RY12 gene and the concentration of P2 $Y_{12}$ molecules in platelets (as well as in megakaryocytes) were correlated with the level of basic markers of platelet activation induced by synthetic thrombin receptor activating peptide 6 (TRAP-6), which is a selective PAR1 agonist, referring to the results of our previously published paper [25]. This data was compiled with correlation parameters for the expression of P2RY12 gene or P2Y 12 proteins vs. the level of PAGs, PMPs, and P-selectin, determined in SP MS blood after ADP stimulation.

\section{Results}

\subsection{The Level of Platelets' Markers of Activation}

As a result of our cytometric analysis, we demonstrated an explicit increase in the percentage of PAGs, PLAs, and PMPs, as well as a higher expression of surface P-selectin in SP MS patients compared to control in ADP-stimulated blood platelets (the results for non-stimulated blood platelets was published previously [25]). The examination of blood platelet responsiveness to the action of ADP $(20 \mu \mathrm{M})$ showed a higher percentage of PAGs (SP MS about 2-fold increase vs. control, $p<0.001$ ) (Figure 1) and PMPs (SP MS almost 2 -fold increase vs. control, $p<0.001$ ) (Figure 2), as well as an elevated surface expression of P-selectin in SP MS platelets (over 2.5-fold vs control, $p<0.001$ ) (Figure 3). All results are the percentage expressed per total pool of 15,000 CD61-positive cells (identified as blood platelets). 


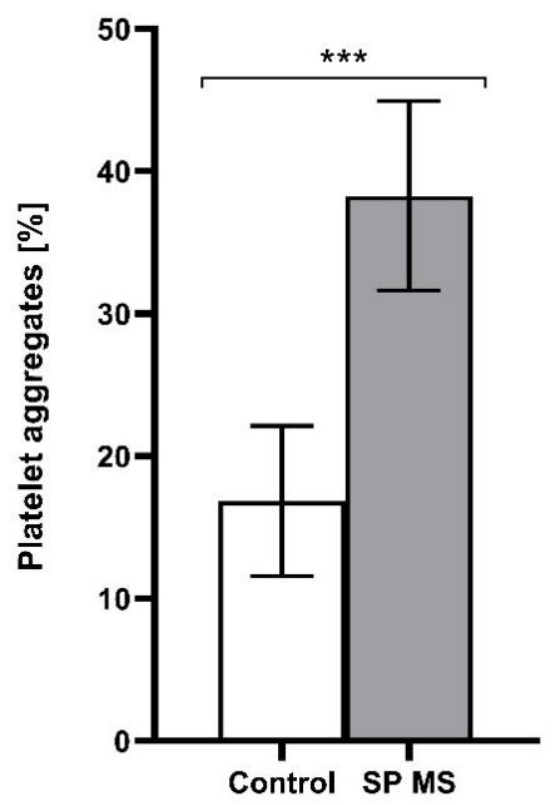

Figure 1. The level of platelet aggregation expressed as a percentage of PAGs relative to the total platelet pool (15,000 CD61-positive objects), measured by flow cytometry method in ADP $(20 \mu \mathrm{M})$ treated blood from the secondary-progressive multiple sclerosis (SP MS) $(n=55)$ and control group $(n=55)$. Statistical analysis was performed using the Mann-Whitney $\mathrm{U}$ test. The data represents the mean percentage of PAGs $\pm \mathrm{SD},{ }^{* * *} p<0.001$.

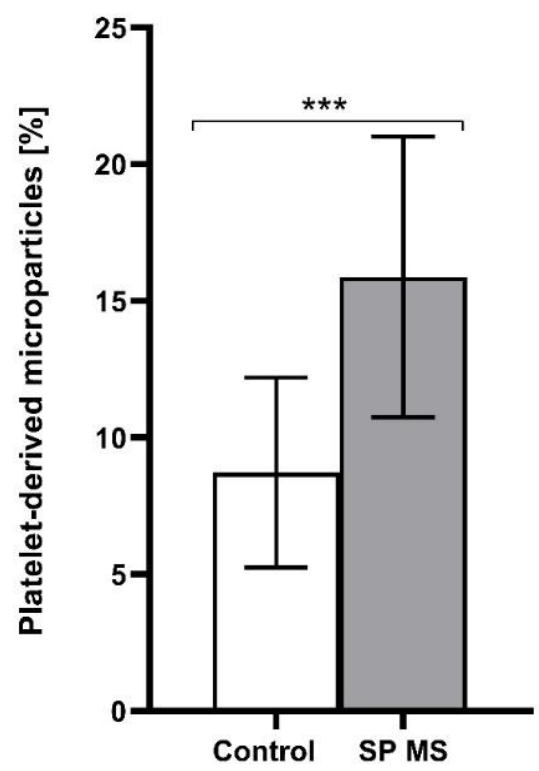

Figure 2. The percentage of PMPs determined relative to the total platelet pool (15,000 CD61-positive objects), measured by flow cytometry method in ADP $(20 \mu \mathrm{M})$-treated blood from the secondaryprogressive multiple sclerosis (SP MS) $(n=55)$ and control group $(n=55)$. Statistical analysis was performed using the Mann-Whitney $U$ test. The data represents the mean percentage of PMPs $\pm S D$, *** $p<0.001$. 


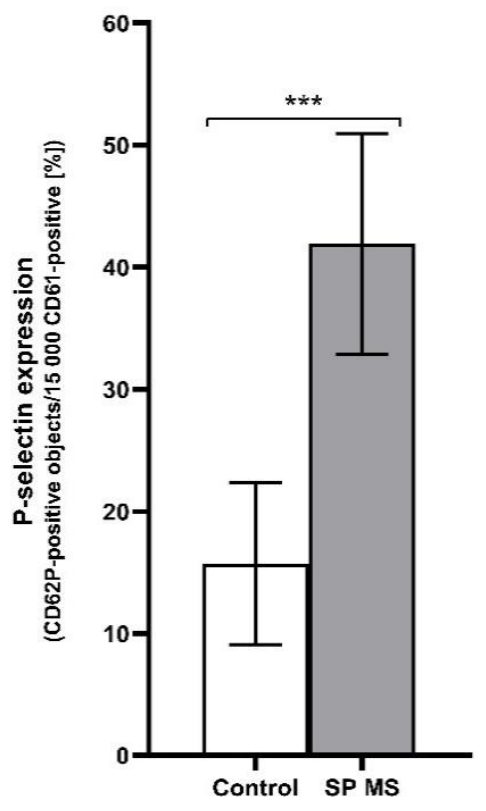

Figure 3. The level of P-selectin expression determined as a percentage of CD61/CD62P-positive objects relative to the total platelet pool (15,000 CD61-positive objects), measured by flow cytometry method in ADP $(20 \mu \mathrm{M})$-treated blood from the secondary-progressive multiple sclerosis (SP MS) $(n=55)$ and control group $(n=55)$. Statistical analysis was performed using the Mann-Whitney $\mathrm{U}$ test. The data represents the mean percentage of exposed P-selectin $\pm \mathrm{SD}$, *** $p<0.001$.

The level of PLAs (as a marker of platelet-leukocyte crosstalk mediated by P-selectin) in ADP-stimulated blood from SP MS was also higher in comparison to the control. Figure 4 includes representative double-fluorescence dot-plots of the percentage of formed PLAs (CD61/CD45-positive objects per 15,000 CD45-positive cells) in ADP-treated blood from the control (Figure $4 \mathrm{a}$ ) and SP MS (Figure $4 \mathrm{~b}$ ).

(a)

CD45

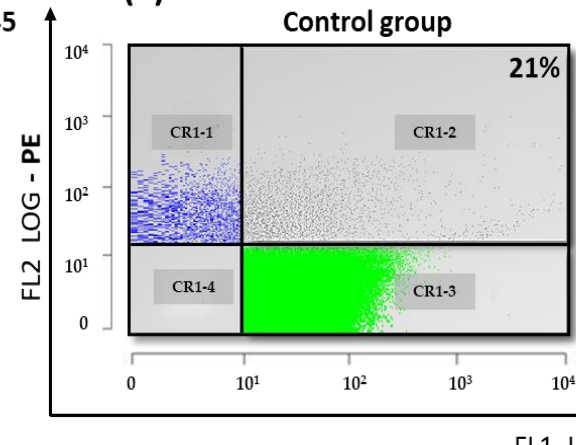

(b)

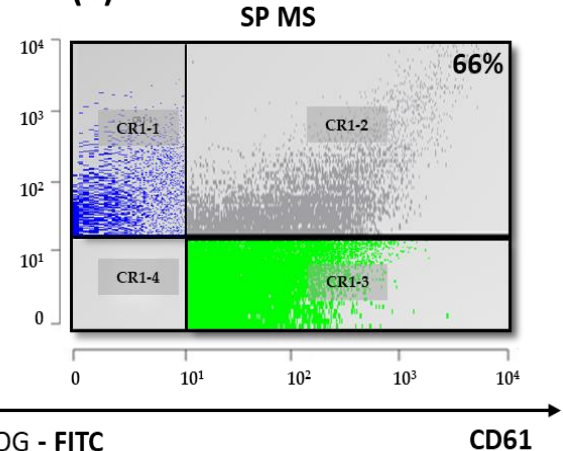

CR1-1 - CD45-positive objects (leukocytes)

CR1-2 - CD61/CD45-positive objects (platelets-leukocyte aggregates) CR1-3 - CD61-positive (blood platelets) CR1-4 - CD61/CD45-negative objects

Figure 4. The representative double-fluorescence dot-plots of the pool of PLAs determined as a percentage of CD61/CD45-positive objects relative to the total leukocyte pool (15,000 CD45-positive objects), measured by flow cytometry method in ADP-treated whole blood from control (left dot-plot) (a) and secondary-progressive multiple sclerosis (SP MS) (right dot-plot) (b). The typical doublefluorescence dot-plots CD61/FITC (FL1) vs. CD45/PE (FL2) represent in log scale the gating strategy for PLAs. Dot-plots are divided into 4 quadrants: CR1-1 (blue dots: CD45-positive objects-leukocytes), CR1-2 (grey dots: CD61/CD45-positive-PLAs), CR1-3 (green dots: CD61-positive objects-platelets), and CR1-4 (represent nonspecific antibody binding, not included in measurement). 


\subsection{The Measurement of PRI [\%]}

In the next step of experiments, we reported a distinctly higher level of the platelet VASP phosphorylation in SP MS patients in comparison to the control group (Figure 5). Blood platelets from almost all blood samples of patients with SP MS reached the maximum level of reactivity in response to ADP $(99.8 \pm 2 \%)$, while the average control PRI was about $20 \%$ lower $(82.1 \pm 5.8 \%)(p<0.001)$.

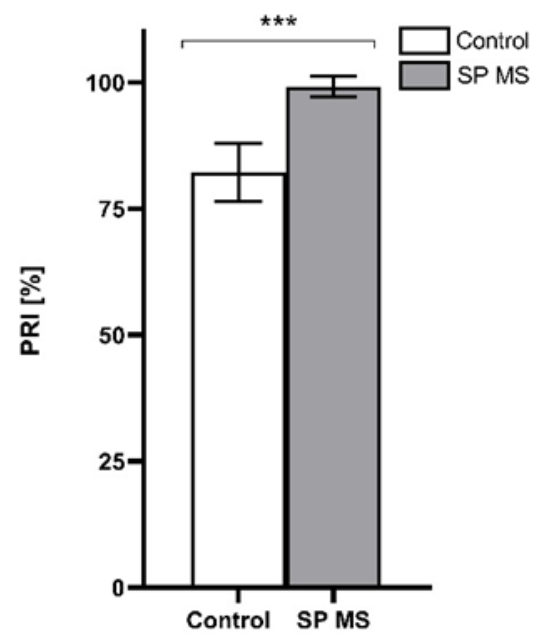

Figure 5. The level of VASP phosphorylation in the analyzed total pool of 15,000 CD61-positive objects after ADP stimulation in the control group $(n=55)$ and secondary-progressive multiple sclerosis (SP MS) patients $(n=55)$, measured by flow cytometry method. Statistical analysis was performed using the Mann-Whitney $\mathrm{U}$ test. The data represents the mean percentage of $\mathrm{PRI} \pm \mathrm{SD}$, *** $p<0.001$.

\section{3. $P 2 Y_{12}$ Receptor Expression on Blood Platelets [\%]}

Based on the flow cytometry analysis, the expression level of surface $\mathrm{P}_{2} \mathrm{Y}_{12}$ receptor as a result of the ADP stimulation was significantly increased in SP MS compared to the control. Figure 6 includes representative histograms for control (a) and SP MS (b).

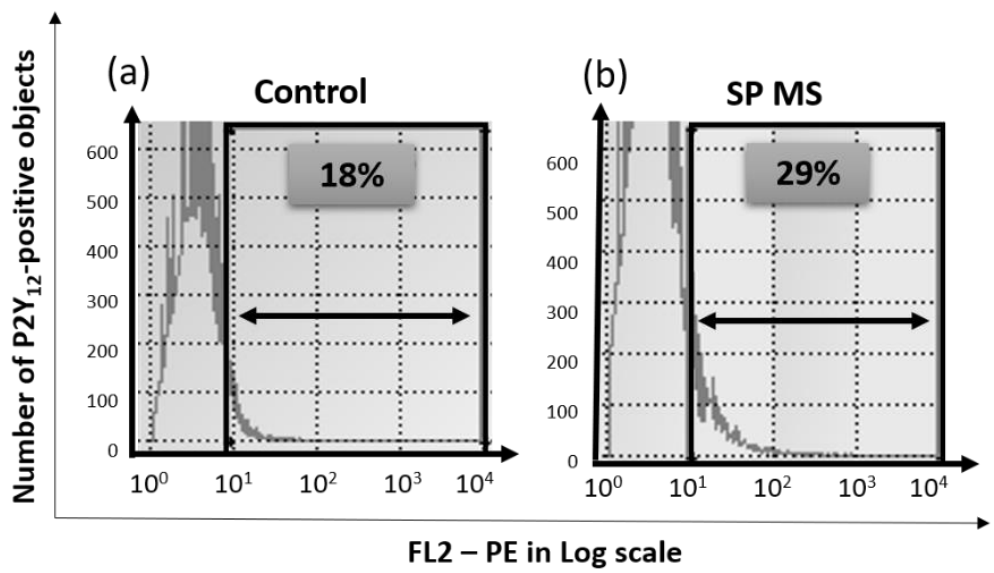

Figure 6. The representative histograms of the expression level of $\mathrm{P}_{2} \mathrm{Y}_{12}$ receptor determined as a percentage of $\mathrm{CD} 61 / \mathrm{P}_{2} \mathrm{Y}_{12}$-positive objects relative to the total platelet pool (15,000 CD61-positive objects), measured by flow cytometry method in ADP-treated blood from the control (a) and secondaryprogressive multiple sclerosis (SP MS) (b) groups.

\section{4. mRNA Expression for P2RY12 Gene in Blood Platelets and Megakaryocytes}

The relative expression of mRNA transcripts for the P2RY12 gene in blood platelets obtained from patients with SP MS was increased approximately 6-fold $(p<0.001)$ in 
comparison to the control group $\left(2^{-\Delta \mathrm{Ct}}\right.$ was $2.82 \times 10^{-4} \pm 2.16 \times 10^{-4}$ in SP MS vs. $0.47 \times 10^{-4} \pm 0.27 \times 10^{-4}$ in control) (Figure 7a). Simultaneously, the level of relative expression of mRNA transcripts for the P2RY12 gene in megakaryocytes was $85 \%$ higher in SP MS compared to the control group $\left(2^{-\Delta \mathrm{Ct}}\right.$ was $1.11 \times 10^{-5} \pm 0.89 \times 10^{-5}$ in SP MS vs. $0.62 \times 10^{-5} \pm 0.49 \times 10^{-5}$ in control) (Figure $7 \mathrm{~b}$ ) .

(a) Blood platelets

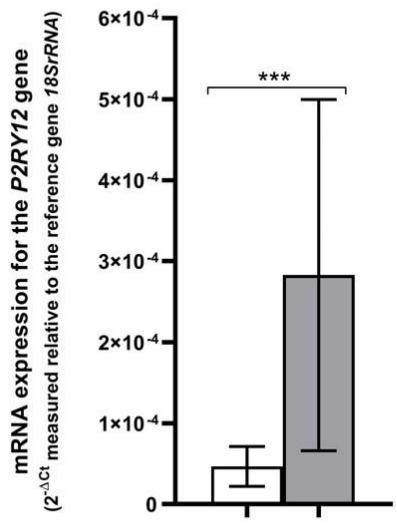

(b) Megakaryocytes

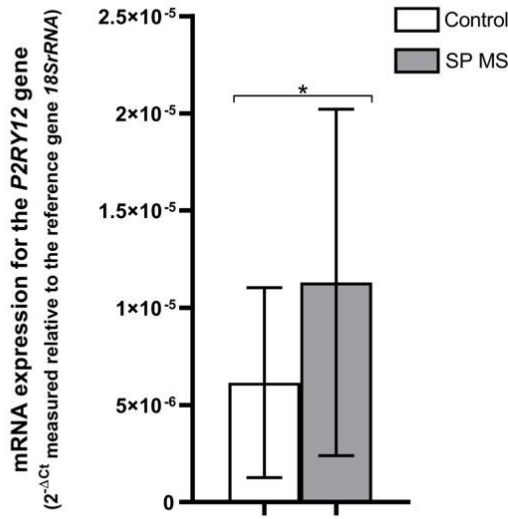

Figure 7. Expression of the $P 2 R Y 12$ gene (measured at the mRNA level) in platelets (a) and megakaryocytes (b) from patients with secondary-progressive multiple sclerosis (SP MS) $(n=55)$ and from controls $(n=55)$. Statistical analysis was performed using the Mann-Whitney $\mathrm{U}$ test. The results are expressed as the mean value of $2^{-\Delta \mathrm{Ct}} \pm \mathrm{SD}$ (according to the reference gene-18SrRNA), ${ }^{*} p<0.05$, *** $p<0.001$.

\subsection{Concentration of $P 2 Y_{12}$ Molecules in Blood Platelets and Megakaryocytes}

Based on the results obtained by the ELISA method, we found that the average concentration of $\mathrm{P}_{2} \mathrm{Y}_{12}$ molecules in lysates of platelets from patients with SP MS $(129.98 \pm 75.24 \mathrm{ng} / \mathrm{mL})$ was about $46 \%$ higher than the concentration in control platelets $(88.93 \pm 61.73 \mathrm{ng} / \mathrm{mL})$ $(p<0.001)$ (Figure 8a), while the mean concentration of $\mathrm{P}^{2} \mathrm{Y}_{12}$ molecules in lysates of megakaryocytes from patients with SP MS was about 35\% higher compared to the average concentration in lysates of control megakaryocytes $(104.52 \pm 19.03 \mathrm{ng} / \mathrm{mL}$ vs. $77.28 \pm 18.16 \mathrm{ng} / \mathrm{mL}$, respectively) $(p<0.001)$ (Figure $8 \mathrm{~b})$

(a)

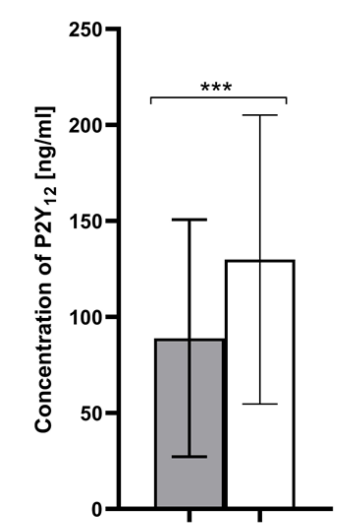

(b)

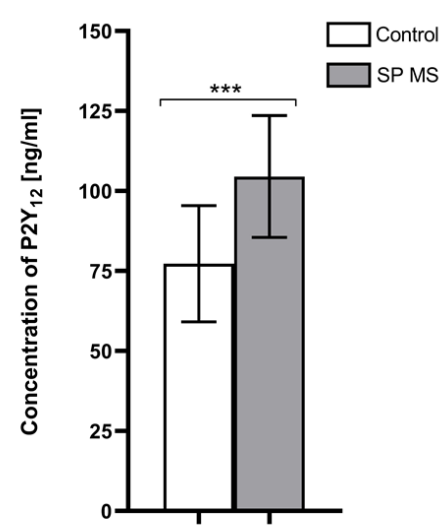

Figure 8. The level of $\mathrm{P}_{2} \mathrm{Y}_{12}(\mathrm{ng} / \mathrm{mL}) \pm \mathrm{SD}$ in blood platelets (a) and megakaryocytes (b) from secondary-progressive multiple sclerosis (SP MS) patients $(n=55)$ and from control group $(n=55)$. Statistical analysis was performed using the Mann-Whitney $\mathrm{U}$ test. The data represents the mean concentration of $\mathrm{P}^{2} \mathrm{Y}_{12} \pm \mathrm{SD},{ }^{* * *} p<0.001$. 
Additionally, we demonstrated a positive correlation between mRNA expression level for the P2RY12 gene or the concentration of $\mathrm{P}_{2} \mathrm{Y}_{12}$ molecules in platelets (as well as in megakaryocytes) and the level of platelet activation markers (PAGs, PMPs, P-selectin surface expression) observed in the blood of SP MS patients after ADP stimulation. Moreover, an analogous statistical analysis was compiled for the mRNA expression level for the $P 2 R Y 12$ gene or the concentration of $\mathrm{P}_{2} \mathrm{Y}_{12}$ molecules and the level of platelet activation markers induced via PAR1 stimulated by the TRAP-6 (based on our previously published data [25]) (Table 1).

Table 1. Correlation coefficient value obtained for concentration of $P 2 Y_{12}$ or $P 2 R Y 12$ mRNA expression and level of platelet activity markers (PAGs, PMPs, and P-selectin) after ADP $(20 \mu \mathrm{M})$ and TRAP-6 $(500 \mu \mathrm{M})$ stimulation. The correlation was analyzed using Spearman's rank correlation (Rho) method. Table consists of Rho with $95 \%$ CI, probability of correlation ( $p$-value), and adjusted $p$-values for multiple tests by Benjamini-Hochberg (FDR), Holm-Sidak, and Bonferroni-Sidak sequential procedures. Corrected $p$-values below 0.05 are considered as statistically significant and highlighted in bold.

\begin{tabular}{|c|c|c|c|c|c|c|}
\hline \multirow{2}{*}{ Agonist } & \multirow{2}{*}{$\begin{array}{c}\text { Platelet Activity } \\
\text { Markers }\end{array}$} & \multicolumn{2}{|c|}{ Spearman's Rank Correlation } & \multirow{2}{*}{$\begin{array}{c}\text { Benjamini-Hochberg } \\
\text { FDR }(\mathrm{Q}=\mathbf{5} \%) \\
\text { Adjusted } \\
p \text {-Value } 1 \#\end{array}$} & \multirow{2}{*}{$\begin{array}{c}\begin{array}{c}\text { Holm-Sidak } \\
(\alpha=0.05)\end{array} \\
\begin{array}{c}\text { Adjusted } \\
p \text {-Value 2 \# }\end{array}\end{array}$} & \multirow{2}{*}{$\begin{array}{c}\begin{array}{c}\text { Bonferroni-Sidak } \\
(\alpha=0.05)\end{array} \\
\text { Adjusted } \\
p \text {-Value } 3 \#\end{array}$} \\
\hline & & Rho $(95 \%$ CI $)$ & $p$-Value & & & \\
\hline \multicolumn{7}{|c|}{ mRNA expression for the $P 2 R Y 12$ gene in control blood platelets $v s$} \\
\hline \multirow{3}{*}{ ADP } & PAGs $[\%]$ & $0.286(0.017-0.516)$ & 0.0328 & 0.0376 & 0.1485 & 0.5509 \\
\hline & PMPs $[\%]$ & $0.337(0.073-0.556)$ & 0.0112 & 0.0202 & 0.1165 & 0.2369 \\
\hline & P-selectin [\%] & $0.355(0.094-0.570)$ & 0.0073 & 0.0143 & 0.0911 & 0.1613 \\
\hline \multirow{3}{*}{ TRAP-6 } & PAGs [\%] & $0.535(0.207-0.756)$ & 0.0023 & 0.0076 & 0.0450 & 0.0538 \\
\hline & PMPs $[\%]$ & $0.426(0.067-0.688)$ & 0.0188 & 0.0279 & 0.1485 & 0.3659 \\
\hline & P-selectin [\%] & $0.478(0.132-0.721)$ & 0.0074 & 0.0143 & 0.0911 & 0.1633 \\
\hline \multicolumn{7}{|c|}{ mRNA expression for the $P 2 R Y 12$ gene in SP MS blood platelets $v s$} \\
\hline \multirow{3}{*}{$\mathrm{ADP}$} & PAGs [\%] & $0.512(0.249-0.705)$ & 0.0003 & 0.0038 & 0.0069 & 0.0072 \\
\hline & PMPs [\%] & $0.441(0.161-0.655)$ & 0.0024 & 0.0076 & 0.0450 & 0.0560 \\
\hline & P-selectin [\%] & $0.327(0.028-0.572)$ & 0.0282 & 0.0338 & 0.1485 & 0.4967 \\
\hline \multirow{3}{*}{ TRAP-6 } & PAGs $[\%]$ & $0.419(0.079-0.673)$ & 0.0150 & 0.0252 & 0.1403 & 0.3042 \\
\hline & PMPs [\%] & $0.392(0.045-0.654)$ & 0.0243 & 0.0306 & 0.1485 & 0.4459 \\
\hline & P-selectin $[\%]$ & $0.369(0.013-0.642)$ & 0.0375 & 0.0411 & 0.1485 & 0.6004 \\
\hline \multicolumn{7}{|c|}{ mRNA expression for the $P 2 R Y 12$ gene in control megakaryocytes $v s$} \\
\hline \multirow{3}{*}{ ADP } & PAGs [\%] & $0.348(0.001-0.621)$ & 0.0436 & 0.0458 & 0.1485 & 0.6570 \\
\hline & PMPs [\%] & $0.394(0.0536-0.652)$ & 0.0213 & 0.0284 & 0.1485 & 0.4035 \\
\hline & P-selectin [\%] & $0.469(0.146-0.702)$ & 0.0051 & 0.0129 & 0.0738 & 0.1155 \\
\hline \multirow{3}{*}{ TRAP-6 } & PAGs [\%] & $0.533(0.203-0.754)$ & 0.0024 & 0.0076 & 0.0450 & 0.0560 \\
\hline & PMPs [\%] & $0.545(0.206-0.755)$ & 0.0023 & 0.0076 & 0.0450 & 0.0538 \\
\hline & P-selectin [\%] & $0.540(0.213-0.759)$ & 0.0021 & 0.0076 & 0.0432 & 0.0492 \\
\hline \multicolumn{7}{|c|}{ mRNA expression for the $P 2 R Y 12$ gene in SP MS megakaryocytes $v s$} \\
\hline \multirow{3}{*}{$\mathrm{ADP}$} & PAGs [\%] & $0.445(0.075-0.707)$ & 0.0177 & 0.0279 & 0.1485 & 0.3486 \\
\hline & PMPs [\%] & $0.577(0.249-0.786)$ & 0.0013 & 0.0076 & 0.0282 & 0.0307 \\
\hline & P-selectin [\%] & $0.553(0.216-0.773)$ & 0.0002 & 0.0038 & 0.0048 & 0.0048 \\
\hline \multirow{3}{*}{ TRAP-6 } & PAGs [\%] & $0.530(0.185-0.759)$ & 0.0037 & 0.0104 & 0.0576 & 0.0851 \\
\hline & PMPs [\%] & $0.499(0.144-0.741)$ & 0.0068 & 0.0143 & 0.0911 & 0.1511 \\
\hline & P-selectin [\%] & $0.433(0.059-0.699)$ & 0.0214 & 0.0284 & 0.1485 & 0.4050 \\
\hline \multicolumn{7}{|c|}{ Concentration of $\mathrm{P}_{2} \mathrm{Y}_{12}$ in control blood platelets $v s$} \\
\hline \multirow{3}{*}{$\mathrm{ADP}$} & PAGs [\%] & $0.418(0.082-0.668)$ & 0.0139 & 0.0350 & 0.1894 & 0.2853 \\
\hline & PMPs [\%] & $0.429(0.097-0.676)$ & 0.0112 & 0.0314 & 0.1870 & 0.2369 \\
\hline & P-selectin [\%] & $0.373(0.029-0.637)$ & 0.0299 & 0.0424 & 0.2354 & 0.5174 \\
\hline \multirow{3}{*}{ TRAP-6 } & PAGs [\%] & $0.379(0.011-0.657)$ & 0.0385 & 0.0424 & 0.2354 & 0.6103 \\
\hline & PMPs [\%] & $0.486(0.146-0.727)$ & 0.0060 & 0.0314 & 0.1240 & 0.1345 \\
\hline & P-selectin [\%] & $0.513(0.176-0.741)$ & 0.0038 & 0.0314 & 0.0838 & 0.0873 \\
\hline
\end{tabular}


Table 1. Cont.

\begin{tabular}{|c|c|c|c|c|c|c|}
\hline \multirow{2}{*}{ Agonist } & \multirow{2}{*}{$\begin{array}{l}\text { Platelet Activity } \\
\text { Markers }\end{array}$} & \multicolumn{2}{|c|}{ Spearman's Rank Correlation } & \multirow{2}{*}{$\begin{array}{c}\text { Benjamini-Hochberg } \\
\text { FDR }(\mathrm{Q}=5 \%) \\
\text { Adjusted } \\
p \text {-Value } 1 \#\end{array}$} & \multirow{2}{*}{$\begin{array}{c}\text { Holm-Sidak } \\
(\alpha=0.05)\end{array}$} & \multirow{2}{*}{$\begin{array}{c}\text { Bonferroni-Sidak } \\
(\alpha=0.05) \\
\text { Adjusted } \\
p \text {-Value } 3 \#\end{array}$} \\
\hline & & Rho $(95 \%$ CI) & $p$-Value & & & \\
\hline \multicolumn{7}{|c|}{ Concentration of $\mathrm{P}_{2} \mathrm{Y}_{12}$ in SP MS blood platelets $v s$} \\
\hline \multirow{3}{*}{ ADP } & PAGs [\%] & $0.312(0.008-0.564)$ & 0.0387 & 0.0424 & 0.2354 & 0.6122 \\
\hline & PMPs [\%] & $0.479(0.204-0.684)$ & 0.0010 & 0.0252 & 0.0237 & 0.0237 \\
\hline & P-selectin [\%] & $0.317(0.013-0.567)$ & 0.0361 & 0.0424 & 0.2354 & 0.5862 \\
\hline \multirow{3}{*}{ TRAP-6 } & PAGs $[\%]$ & $0.358(0.000-0.627)$ & 0.0441 & 0.0463 & 0.2354 & 0.6612 \\
\hline & PMPs [\%] & $0.367(0.016-0.634)$ & 0.0358 & 0.0424 & 0.2354 & 0.5831 \\
\hline & P-selectin [\%] & $0.393(0.041-0.658)$ & 0.0259 & 0.0424 & 0.2354 & 0.4673 \\
\hline \multicolumn{7}{|c|}{ Concentration of $\mathrm{P}_{2} \mathrm{Y}_{12}$ in control megakaryocytes $v s$} \\
\hline \multirow{3}{*}{ ADP } & PAGs [\%] & $0.496(0.139-0.739)$ & 0.0073 & 0.0314 & 0.1426 & 0.1613 \\
\hline & PMPs [\%] & $0.425(0.050-0.695)$ & 0.0241 & 0.0424 & 0.2354 & 0.4432 \\
\hline & P-selectin [\%] & $0.475(0.112-0.726)$ & 0.0107 & 0.0314 & 0.1870 & 0.2275 \\
\hline \multirow{3}{*}{ TRAP-6 } & PAGs [\%] & $0.406(0.027-0.683)$ & 0.0320 & 0.0424 & 0.2354 & 0.5418 \\
\hline & PMPs $[\%]$ & $0.438(0.066-0.703)$ & 0.0197 & 0.0384 & 0.2333 & 0.3797 \\
\hline & P-selectin [\%] & $0.439(0.066-0.703)$ & 0.0198 & 0.0384 & 0.2333 & 0.3812 \\
\hline \multicolumn{7}{|c|}{ Concentration of $\mathrm{P}_{2} \mathrm{Y}_{12}$ in SP MS megakaryocytes $v s$} \\
\hline \multirow{3}{*}{ ADP } & PAGs [\%] & $0.476(0.115-0.727)$ & 0.0103 & 0.0314 & 0.1870 & 0.2200 \\
\hline & PMPs [\%] & $0.472(0.108-0.724)$ & 0.0112 & 0.0314 & 0.1870 & 0.2369 \\
\hline & P-selectin [\%] & $0.473(0.110-0.725)$ & 0.0110 & 0.0314 & 0.1870 & 0.2331 \\
\hline \multirow{3}{*}{ TRAP-6 } & PAGs [\%] & $0.413(0.036-0.687)$ & 0.0288 & 0.0424 & 0.2354 & 0.5041 \\
\hline & PMPs [\%] & $0.400(0.021-0.679)$ & 0.0349 & 0.0424 & 0.2354 & 0.5737 \\
\hline & P-selectin [\%] & $0.441(0.069-0.705)$ & 0.0188 & 0.0384 & 0.2333 & 0.3659 \\
\hline
\end{tabular}

\section{Discussion}

Blood platelets can be activated by various agonists that bind to specific membrane receptors on the platelet surface. Thus, stimuli such as ADP (thrombin, collagen, and others) activate specific transmembrane receptors that transmit activation signals into the cell. This transduction induces changes in second messenger concentrations, which in turn trigger cellular responses [38].

The purinergic P2Y receptors form the most numerous group of receptors on the

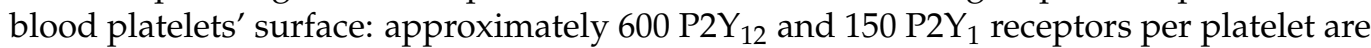
present $[39,40]$. These metabotropic receptors contribute separately to the complex process of ADP-induced platelet aggregation; the $\mathrm{P}_{2} \mathrm{Y}_{1}$ receptor is responsible for mobilization of ionized calcium from internal stores, which initiates aggregation, while the $\mathrm{P} 2 \mathrm{Y}_{12}$ receptor supports the gradual, irreversible stage of platelet aggregation by inhibition of ADPmediated generation of cyclic adenosine monophosphate (cAMP), a negative regulator of platelet activation [41]. Extracellular ADP acts as a direct platelet agonist, but when it is released from platelet storage granules, it acts to expand platelet activation induced by other stimuli [42]. $\mathrm{P}_{2} \mathrm{Y}_{12}$ is the key ADP receptor that amplifies platelet responses induced by other agonists $[43,44]$. It has been proven that mice lacking in $\mathrm{P}_{2} \mathrm{Y}_{12}$ show decreased GPIIb/IIIa activation and reduced adhesion to von Willebrand factor (vWF) [45]. What is more, an irreversible platelet aggregation mediated by both thrombin receptors PAR1 and PAR4 is largely dependent on stimulation of the P2 $\mathrm{Y}_{12} / \mathrm{Gi}$ pathway by ADP released from platelets $[46,47]$. The thrombin is one of the strongest activators of platelets and influences some different signaling pathways. PAR4 forms a dimer with $\mathrm{P}_{2} \mathrm{Y}_{12}$ receptor by activating the $\mathrm{P}_{2} \mathrm{Y}_{12} / \mathrm{PI} 3 \mathrm{~K}$ pathway, causing an increase in the stabilization of the formed platelet clot $[48,49]$. However, according to literature data, PAR1 receptor is mainly responsible for increased expression of $\mathrm{P}_{2} \mathrm{Y}_{12}$ mRNA, total $\mathrm{P}_{12} \mathrm{Y}_{12}$ cellular protein, and cell surface expression (on cultured human vascular smooth muscle cells) due to exposure to thrombin [27]. 
The risk of ischemic incidents such as myocardial infarction and stroke in MS [20,50,51] may raise a question about the level of spontaneous activity and hyperresponsiveness of platelets in this disorder. The pathogenic role of platelets in MS seems to have a multifactorial mechanism. The platelet activation and the role of platelets in hemostatic mechanisms in the further development of the disease in the SP stage have been the subject of our intensive studies for a few years. Our research implies that blood platelet activation in MS could be a phenomenon consequent to the disease's development, likely as an effect of secondarily endothelial injury, which provides an additional subendothelial stimuli for blood platelet activation [52]. In the previous study, we demonstrated that the level of typical biomarkers of platelet activation was elevated in blood obtained from SP MS patients compared to control $[23,25]$. The higher baseline level of the activation stage in SP MS platelets has proven a spontaneous activation in vivo. Moreover, we have indicated that blood platelets from SP MS have an increased COX-dependent arachidonic acid metabolism. Higher COX activity leads to increased aggregation and degranulation of platelets and TXA2 synthesis [53]. Furthermore, COX rapidly metabolizes free arachidonic acid to prostaglandin $\mathrm{H} 2$ (PGH2), causing the burst of oxygen consumption. Reactive oxygen species (ROS) generation induces harmful lipid peroxidation that is responsible for changes in the permeability of the membrane, and exposition of the platelet receptors, and results in changes in signal transduction [54]. Chronic inflammation and high activity of pro-oxidative processes are the main factors identified as a cause of excessive platelet activation in SP MS.

We evaluated the baseline level of platelet activation immediately after the collection of whole blood, being their natural environment, without platelet isolation, to diminish the risk of triggered activation and creation of artefacts. However, platelet reactivity in response to an action of exogenous stimuli, analogous to physiological agonist, is also a very important parameter specifying the reactivity of platelets ex vivo. Platelet availability in response to the physiological agonists is also a measure of depletion of circulating platelets, which is characteristics of chronic activation. Our current goal has been to follow the ADP-mediated platelet activation pathway. The analysis of blood platelet responsiveness to the action of ADP included measuring the typical activation markers (Figures 1-3) and showed the enhanced reactivity of platelets in SP MS. The levels of platelet PAGs, PMPs and P-selectin (CD62P) surface expression were cytometrically determined in whole blood treated with ADP $(20 \mu \mathrm{M})$. Flow cytometry analysis is a sensitive method routinely used both in diagnostics and in basic research. The measurement in whole blood using flow cytometric assay determines both the activation state of circulating platelets and their reactivity, if it is done with the addition of external platelet agonists. Platelet activation is accompanied by the formation of PAGs and the release of PMPs. PMPs represent approximately $80 \%$ of circulating microparticles in the blood of healthy individuals [38], but the research by Giacomazzi et al. showed that increased production of platelet agonists is required to amplify PMPs shedding. In their studies, ADP-triggered PMPs shedding was dose-independent [55]. What is especially interesting, under experimental conditions, is that collagen-induced formation of PMPs in whole blood is dependent on ADP released from red blood cells, and the blockade of platelet ADP receptors, both P2 $\mathrm{Y}_{12}$ and P2Y, suppressed collagen-induced PMPs generation [56]. Strong inhibition levels of collagenand TRAP-6-induced PMPs formation in vitro and their correlation with $\mathrm{P}_{2} \mathrm{Y}_{12}$ receptor blockade were also observed by Judge et al., reflecting the fact that ADP, acting via P2Y $\mathrm{Y}_{12}$, amplifies the cell responses initiated via the GPVI and PAR1 receptor [57]. Clinical studies confirmed a reduction in PMPs generation in patients with ischemic syndromes treated with clopidogrel, a well-known P2 $\mathrm{Y}_{12}$ antagonist. Clopidogrel has been shown to provide clinical benefit in coronary syndromes by inhibition of TRAP-6-induced aggregation, procoagulant activity (exposure of phosphatidylserine providing a negatively charged procoagulant surface), P-selectin expression, and PMPs production [58]. Increased levels of PAGs and PMPs in the peripheral blood indicate not only a higher pro-coagulant but also pro-inflammatory potential in SP MS [59-61]. PMPs take part in cellular communication 
systems, transmitting remote signals from cell to cell, and particularly, in promoting the spread of inflammation [62].

The putative role of activated blood platelets in the development of vessel inflammatory response is due to their ability to adhere to sites of injury, as well as the capacity of platelets to create an aggregates with leukocytes [63]. Platelet secretory responses favor homo- and hetero-aggregates formation as well as heterotypic interactions with, and adhesion to, other vascular, immune, and inflammatory cells [64]. The cell-cell interaction initiates critical mechanisms by which platelets are able to cross-link inflammation and thrombosis [65]. During activation, blood platelets expose a vast number of membrane receptors, and release signaling molecules and soluble mediators from their granules inducing recruitment and activation of additional platelets, resulting in faster clot formation $[66,67]$. The releasing of biologically active compounds from platelet granules is an extremely important phenomenon, which may induce pro-inflammatory conditions in surroundings of activated platelets. Secreted molecules from granules act in an auto- or paracrine fashion to modulate cell signaling [68]. One of the major biomarkers of the functional status of blood platelets is P-selectin (CD62P), a glycoprotein stored in $\alpha$-granules of resting platelets. The measurement of $\mathrm{CD} 62 \mathrm{P}$ expression on the platelet surface reflects an actual state of the cell degranulation, and for this reason, is a reliable and practical implementation to monitor the activation level of platelets in vivo and in vitro [69]. Our results demonstrated the almost 3-fold higher percentage of P-selectin $(p<0.001)$ exposure after ADP action in whole blood of patients with SP MS, relative to healthy controls (Figure 3). It is particularly noteworthy that despite elevated baseline levels of platelet activation markers in the progressive phase of MS (which was presented in [25]), blood platelets still release large amounts of P-selectin from $\alpha$ granules, and show enhanced reactivity after ADP stimulation, what only demonstrate their strong pro-thrombotic potential. CD62P molecules are among the antigens that are temporarily expressed on the blood platelet surface. and over time, undergo proteolytic cleavage into plasma as a soluble P-selectin (sP-selectin) [70]. It is particularly important because sP-selectin retains its functionality in circulation, and the elevated plasma level of sCD62 is associated with several inflammatory disorders. In our previous work, we have demonstrated higher sP-selectin levels in the plasma of SP MS subjects than in the control group [23]. During the activation of platelets, the CD62P is exposed on their surface, and allows interaction between leukocytes (mainly monocytes and neutrophils) via P-selectin glycoprotein ligand-1 (PSGL-1) presented on leukocytes' surface. Interaction with CD62P/PSGL-1 has a crucial role in leukocyte rolling and contributes to leukocyte recruitment and extravasation, which enables the link between PLAs and dysfunctional endothelium, which is the key element in blood vessels prone to inflammation development [71]. Selective recruitment of leukocytes occurs in the inflamed areas of damaged vessels, where proteins of the subendothelial layer are exposed and the level of CD62P is enhanced as a result of the deposition of a large number of active platelets [6]. A study conducted by Dixon et al. showed that CD62P/PSGL-1 interactions enhance monocyte COX-2 expression and increase synthesis of pro-inflammatory prostaglandin E2 (PGE2) through molecular mechanisms including cellular adhesion and cytokine signaling [72]. In addition to CD62P, platelets release from their granules a wide variety of other highly bioactive mediators, such as platelet factor 4 (PF-4), transforming growth factor $\beta$ (TGF- $\beta$ ), RANTES (Regulated on Activation, Normal T Cell Expressed and Secreted), platelet-derived growth factor (PDGF), proteases, and interleukin $1 \beta$ (IL-1 $\beta$ ), which, following release from granules, can participate in platelet aggregation, thrombosis, platelet adhesive interactions with leukocytes, and regulation of cell proliferation [73].

We have shown that the level of PLAs in ADP-stimulated blood from SP MS was higher in comparison to the control, which is presented visually on representative dot-plots in Figure 4. It is known that after the formation of PLAs, the production of pro-inflammatory molecules, such as cytokines and leukotrienes is triggered [69]. Platelet-leukocyte interaction occurring as a consequence of platelet activation plays a key role in the deposition of activated platelets in demyelinating lesions in MS, which leads to brain neurodegenera- 
tion [74]. It is believed that the expression of CD62P on the platelet surface fully reflects cell degranulation, while the measurement of its level is a useful tool to monitor the activation status of platelets in vitro and in vivo [75]. A relatively recent study by Habets et al. emphasized the role of platelets in the course of rheumatoid arthritis, an autoimmune disease accompanied by inflammation, analogous to MS. The authors demonstrated an increased expression of P-selectin and elevated platelet aggregation, and most notably, positive correlation between the activation of platelets and disease activity in rheumatoid arthritis [76]. As current knowledge about the mechanisms underlying pathogenesis of MS is still fragmentary, it should be noted that the mutual cellular interactions between platelets, immune cells, and endothelium are closely related to the activation of all types of these cells, which can have serious consequences for maintaining the tightness of BBB and further development of local inflammatory response in CNS [77].

Thus, the increased reactivity of platelets in response to the action of ADP released under pathological conditions in MS may result in the amplification of pro-thrombotic and pro-inflammatory events, also initially triggered by other agonists. We also confirmed a high blood platelet responsiveness to the action of ADP in a flow cytometry diagnostic test based on the VASP phosphorylation level assessment that negatively correlates with the degree of platelet activation in a pathway mediated by the $\mathrm{P}_{2} \mathrm{Y}_{12}$ receptor. VASP is an intracellular platelet protein, which belongs to profilin or actin-binding proteins, and is involved in cytoskeleton reorganization, adhesion, and platelet aggregation. VASP phosphorylation is upregulated by the cAMP cascade, and ADP inhibits this process through $\mathrm{P}_{2} \mathrm{Y}_{12}$ receptors. It can, therefore, be proposed that the phosphorylated state of VASP is a specific intracellular marker of $\mathrm{P}_{2} \mathrm{Y}_{12}$ receptor reactivity, because the low level of the phosphorylated form of VASP is correlated with increased $\mathrm{P}_{2} \mathrm{Y}_{12}$ receptor activity [78]. The results of VASP phosphorylation are presented as a percentage value of PRI. Our analysis established that PRI reached almost the maximum level $(99.1 \pm 2 \%)$ in all samples from SP MS patients, while the average control platelet reactivity was about $20 \%$ lower (Figure 5).

In this work, we have demonstrated that the level of surface $\mathrm{P}_{2} \mathrm{Y}_{12}$ receptor expression, measured cytometrically as a result of ADP stimulation, was significantly increased in SP MS compared to the control, which is presented visually in Figure 6 . What is more, to verify potential genetic and proteomic abnormalities of the platelet $\mathrm{P}_{2} \mathrm{Y}_{12}$ receptor, which could be a potential cause of its increased ADP-induced activity, we performed a comparative analysis of $\mathrm{P}_{2} \mathrm{Y}_{12}$ expression both at the mRNA level and in the protein concentration of this receptor's molecules. In recent years, it has been shown that in blood platelets, despite the lack of a cell nucleus, protein synthesis takes place based on mRNA derived from megakaryocytes, the giant bone marrow cells that are precursors of platelets [79,80], while other platelet proteins are synthesized in megakaryocytes and flow from mature megakaryocytes to the constituted platelets [81]. Therefore, the recognition of the genetic factors responsible for molecular changes of platelet proteome should be defined both at the stage of platelets and megakaryocytes. Following this thought, we performed multidirectional analysis to find the molecular changes at the mRNA and protein levels in both platelets and megakaryocytes. For the first time, we found that mRNA expression for the $P 2 R Y 12$ gene was enhanced in both platelets and megakaryocytes of SP MS patients (Figure 7), and this was reflected in the increased platelet P2 $\mathrm{Y}_{12}$ copy number (Figure 8). Considering our results obtained for megakaryocytes, we can suppose that the changes in P2RY12 mRNA expression observed in SP MS platelets may already occur in precursor cells, before being phenotypically revealed in platelets.

Focusing on the molecular aspects of enhanced platelet activation through the ADP/ P2 $Y_{12}$ pathway, we also analyzed the influence of the PAR1-dependent pathway on P2Y 12 signaling. Due to the established association between the PAR1 signaling pathway and cellular expression of $\mathrm{P}_{2} \mathrm{Y}_{12}$, the level of mRNA for the P2RY12 gene and the concentration of $\mathrm{P}_{2} \mathrm{Y}_{12}$ platelet molecules were correlated with the level of typical markers of platelet activation induced by TRAP-6, a selective PAR1 agonist, referring to the results of our 
previously published paper [25]. This data was compiled with correlation parameters for expression of the P2RY12 gene or P2 $\mathrm{Y}_{12}$ proteins vs. the level of PAGs, PMPs, and P-selectin, determined in SP MS blood after ADP and TRAP-6 stimulation. Our analysis showed for the first time that the relative mRNA transcript expression for the P2RY12 gene and the concentration of $\mathrm{P}_{2} \mathrm{Y}_{12}$ proteins are significantly correlated with all parameters of platelet activation, both ADP- and TRAP-6-induced (Table 1). Positive correlations between $\mathrm{P}^{2} \mathrm{Y}_{12}$ cellular expression and the level of activation markers formed analogously to the exposure of platelets to thrombin may provide evidence for the influence of the PAR1 receptor pathway on $\mathrm{ADP} / \mathrm{P}_{2} \mathrm{Y}_{12}$ signaling.

\section{Materials and Methods}

\subsection{Cytometric Measurements}

The level of classic markers of platelet activation, viz. formation of PAGs, PMPs, and PLAs, as well as the $\mathrm{P}_{2} \mathrm{Y}_{12}$ and P-selectin (CD62P) surface expression, were evaluated using flow cytometry analysis. The fresh whole blood samples, activated with ADP $(20 \mu \mathrm{M}$, $\left.10 \mathrm{~min}, 37^{\circ} \mathrm{C}\right)($ Chrono-Log Corp., Havertown, PA, USA) or TRAP $(500 \mu \mathrm{M}, 10 \mathrm{~min}$, $37^{\circ} \mathrm{C}$ ) (Sigma-Aldrich, St. Louis, MO, USA) or without agonist, were fixed in $1 \%$ Cellfix (Becton Dickinson, San Diego, CA, USA) solution for $1 \mathrm{~h}$ at $37^{\circ} \mathrm{C}$, and stained with anti-

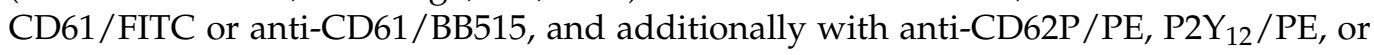
anti-CD45/PE antibodies (30 min. in dark, $25^{\circ} \mathrm{C}$ ). Flow cytometry antibodies: CD61/FITC, anti-CD61/BB515, anti-CD62P/PE and anti-CD45/PE were purchased from BD Biosciences (San Jose, CA, USA), while P2 $\mathrm{Y}_{12} / \mathrm{PE}$ antibody was from BioLegend (San Diego, CA, USA). Against the analysis, the prepared samples were dissolved in $0.9 \% \mathrm{NaCl}(20: 1)$ and vortexed. Fluorescence of 15,000 events (CD61- or CD45-positive objects, platelets, and leukocytes, respectively) was measured each time. Gates for PE and FITC fluorescents were assessed based on the fluorescence of unstained probes. All CD61-positive objects with a parameter FSC below $10^{2}$ were characterized as PMPs, and those above $10^{3}$ as PAGs, while CD61/CD45-positive objects were recognized as PLAs. Surface expression of $\mathrm{P}$-selectin or $\mathrm{P}_{2} \mathrm{Y}_{12}$ on CD61-positive cells was determined by fluorescence of CD62/PE or $\mathrm{P}_{2} \mathrm{Y}_{12} / \mathrm{PE}$, respectively. The percentage of CD62P-positive platelets was calculated relative to the total pool of platelets in each sample (15,000 CD61-positive objects), while the level of CD61/CD45-positive objects (PLAs) was calculated relative to the total pool of leukocytes (15,000 CD45-positive objects) measured in each sample. All data analyses were performed in Cube 6 flow cytometry with CyView Software v 1.5.5.8 (Sysmex Partec, Görlitz, Germany).

\subsection{Assessment of PRI Using the VASP/P2Y $Y_{12}$ Assay}

To monitor a specific response of blood platelets to ADP, we used the VASP/P2Y 12 flow cytometric kit (BioCytex, Marseille, France) [82]. Under the study conditions, the phosphorylation of VASP correlates with the inhibition of the P2 $\mathrm{Y}_{12}$ receptor, whereas in the non-phosphorylated state, it is associated with the active form of the $\mathrm{P}_{2} \mathrm{Y}_{12}$ receptor. The blood samples are incubated with prostaglandin E1 (PGE1) alone, or with PGE1 combined with ADP. After cellular permeabilization, phosphorylated VASP is immunolabeling using the specific monoclonal antibody (anti-VASP-P). Application of double-labelled flow cytometry analysis allows the comparison of two tested conditions and evaluation of the capability of ADP to inhibit VASP phosphorylation in each sample. The PRI was calculated using the correct mean fluorescence intensities (MFIc) in the presence of PGE1 alone or PGE1 with ADP simultaneously, according to the manufacturer's protocol. The PRI is calculated by using the following calculation: PRI [\%] = [(MFIc PGE1 - MFIc PGE1 + ADP)/ MFIc PGE1] $\times 100$. The physiological value of the PRI in the control group should be higher than $70 \%$ [83]. 


\subsection{Isolation of Blood Platelets}

From whole blood samples using differential centrifugation (1200 rpmi, $12 \mathrm{~min}, 25$ ${ }^{\circ} \mathrm{C}$ ), a platelet-rich plasma (PRP) was obtained. To remove erythrocyte/leukocyte contamination, the PRP was purified using nano-sized MicroBeads conjugated, respectively, to monoclonal human antibodies CD235a and CD45 (Miltenyi Biotec, Bergisch Gladbach, Germany). Then, the PRP was loaded in the appropriate amount onto a MACS MS Column, which was placed in the magnetic field of a MiniMACS Separator. The magnetically labelled CD235a-positive and CD45-positive cells were retained on the column, and freeflowing purified blood platelets were collected in a sterile tube. The quantity of platelets was established photometrically [84], and the final concentration of the platelet suspension was each time diluted to $2 \times 10^{8}$ platelets $/ \mathrm{mL}$. The platelet suspension was divided into two equal portions; into one part, the RNALater solution (Invitrogen, Carlsbad, CA, USA) was added, and into the second part, cell lysing buffer ( $2 \mathrm{M}$ thiourea, $7 \mathrm{M}$ urea, $4 \%$ CHAPS, $30 \mathrm{mM}$ Tris) (Sigma-Aldrich, St. Louis, MO, USA) was added. They were then immediately frozen $\left(-80^{\circ} \mathrm{C}\right)$ for further transcriptomic and proteomic analysis.

\subsection{Isolation of Megakaryocytes}

At first, the peripheral blood mononuclear cells (PBMCs) were isolated by density gradient centrifugation. Fresh whole blood was layered in portions (1:1 ratio) onto Gradisol G (Aqua-Med, Lodz, Poland), and centrifuged (2000 rpmi, $\left.30 \mathrm{~min}, 25^{\circ} \mathrm{C}\right)$. Next, the buffy coat layer with PBMCs fraction was carefully collected, washed twice using PBS (pH 7.4) (Biosigma, Venice, Italy), and centrifuged (1600 rpmi, $12 \mathrm{~min}, 25^{\circ} \mathrm{C}$ ). Obtained PBMCs sediment was suspended in reaction buffer ( $\mathrm{pH} 7.4)$ ( 2 mM EDTA, 0.5\% BSA, PBS pH 7.4). The second step is a magnetic separation, in which the CD61-positive PBMCs (megakaryocytes) were firstly labelled with anti-CD61 MicroBeads. Subsequently, the cell suspension was loaded onto a MACS Column placed in the magnetic field of a MACS Separator. The megakaryocytes retained on the column were flushed out together with applied reaction buffer by strongly pushing the plunger in the column. Finally, megakaryocyte suspension was divided into two equal portions; into one part, the RNALater solution (Invitrogen, Carlsbad, CA, USA) was added, and into the second part, cell lysing buffer (2 M thiourea, $7 \mathrm{M}$ urea, $4 \%$ CHAPS, $30 \mathrm{mM}$ Tris) (Sigma-Aldrich, St. Louis, MO, USA) was added. The samples were then immediately frozen $\left(-80^{\circ} \mathrm{C}\right)$ for further transcriptomic and proteomic analysis.

\subsection{Isolation of $m R N A$ and $c D N A$ Synthesis}

Total RNA was isolated from frozen $\left(-80^{\circ} \mathrm{C}\right)$ blood platelets and megakaryocytes suspended in RNALater solution using the ISOLATE II RNA Mini Kit (Bioline, London, UK), which contains a set of reagents that permit inactivation of RNases while stabilizing RNA and allows complete separation from proteins and DNA. Total RNA purity and concentration were measured by comparing the absorbance at 260 and $280 \mathrm{~nm}$, and then samples of total RNA were stored at $-80^{\circ} \mathrm{C}$ until use. The RT-PCR reaction was accomplished using the Maxima First Strand cDNA Synthesis Kit for RT-qPCR (Thermo Fisher Scientific, Waltham, MA, United States) according to the manufacturer's protocol.

\subsection{Expression of the P2RY12 Gene at the mRNA Level in Blood Platelets and Megakaryocytes}

The analysis of the gene expression for the $\mathrm{P}_{2} \mathrm{Y}_{12}$ molecule was made using TaqMan probes: for the human P2RY12 gene (Hs01881698_s1), as endogenous control, human 18SrRNA (Hs99999901_s1) was used (Life Technologies, Carlsbad, CA, USA). Gene expression measurements were made on the Real-Time PCR-The CFX96TM Touch System (Bio-Rad, Hercules, CA, USA) using a TaqMan Universal Master Mix II, no UNG (Life Technologies, Carlsbad, CA, USA). The entire procedure was executed under the manufacturer's protocol. To calculate the relative expression of studied genes, the equation $2^{-\Delta \mathrm{Ct}}$ $\left(\Delta \mathrm{Ct}=\mathrm{Ct}_{\text {target gene }}-\mathrm{Ct}_{18 S r R N A}\right)$ was used. 


\subsection{Concentration of $P 2 Y_{12}$ Receptor in Blood Platelets and Megakaryocytes}

The level of $\mathrm{P}_{2} \mathrm{Y}_{12}$ receptor was measured in blood platelets and megakaryocytes using the commercial Human P2Y $\mathrm{Y}_{12}$ ELISA Kit (Fine Test, Wuhan, China) according to the manufacturer's protocol. All measurements were made using MaxiSorp plates (Nunc, Roskilde, Denmark). Absorbance was measured at $450 \mathrm{~nm}$ using the SPECTROStar Nano Microplate Reader (BMG Labtech, Ortenberg, Germany). The concentration of $\mathrm{P}_{2} \mathrm{Y}_{12}$ in blood platelet and megakaryocyte was determined based on a standard curve expressed as $\mathrm{ng} / \mathrm{mL}$.

\subsection{Statistical Analysis}

All results were expressed as mean $\pm \mathrm{SD}$. The statistical analyses were performed using Sigma Plot version 14.0 (Systat Software, Inc., San Jose, CA, USA). The results obtained were firstly analyzed for normal distribution with the Shapiro-Wilk test. The significance of the differences between the values obtained from patients with SP MS and controls were analyzed using the unpaired Student's t-test (for normal distribution) or the Mann-Whitney U test (for non-normal distribution). Spearman's rank correlation was used for interdependence analysis between $\mathrm{P}_{2} \mathrm{Y}_{12}$ expression and platelet activation markers. Multiple comparisons were performed using Benjamini-Hochberg, Holm-Sidak, and Bonferroni-Sidak corrections. Throughout the analysis, a level of $p<0.05$ was considered statistically significant. All graphs were prepared using GraphPad Prism 8.0. (GraphPad Software, San Diego, CA, USA).

\section{Conclusions}

Defining the complex pathomechanisms of MS and the identification of targets specific to individual pathology is fundamental for the development of therapies. The chronic activation of platelets and their over-reactivity in MS is already proven, but the mechanisms of this pathology still need to be clarified. Much remains to be done in terms of understanding of the molecular basis of specific defects of platelet signaling pathways. Currently, based on our findings, we conclude that targeting the platelet P2 $\mathrm{Y}_{12}$ / ADP pathway may represent a novel therapeutic approach to suppression of the adverse pro-thrombotic consequences in MS. Moreover, due to the molecular studies assessing the cellular level of $\mathrm{P}^{2} \mathrm{Y}_{12}$ expression, it is possible to predict, in patients with SP MS, the risk of developing the consequences of the platelet prothrombotic phenotype.

\section{Patients \\ Clinical Characteristics of Patients}

Blood samples from SP MS patients and the control group were collected into CPDA-1 (citrate phosphate dextrose adenine-1) Sarstedt ${ }^{\circledR}$ tubes (Nümbrecht, Germany), in the morning (8-9 a.m.), in fasting status, and stored under the same conditions, according to one established protocol.

The study samples were obtained from 55 patients (female $n=32$; male $n=23$ ) diagnosed with SP MS. Patients were observed for one year and diagnosed according to the revised McDonald criteria by MRI as the requirement and gold standard for MS diagnosis [85], while secondary progressive course of MS (not active with progression) was ascertained as defined by Lublin et al. [86]. The blood samples from SP MS patients were collected at the Neurological Rehabilitation Division III General Hospital in Lodz, Poland. The SP MS patients were under observation at the Neurorehabilitation Ward for three weeks, during which time they did not receive any immunostimulators, immunomodulators, or hormones. The clinical parameters of enrolled SP MS patients are included in Table 2. The EDSS scale ranges from 0 to 10 (in 0.5 unit increments), representing the level of the patient's disability [87]. BDI evaluation is one of the most widely used psychometric tests for measuring the severity of depression. It is categorized into four types: normal $(\leq 9)$, minimal depressive symptomatology (10-15), mild depression (16-31), moderate (32-47), and severe depression $(\geq 47)[88]$. 
Table 2. Clinical characteristics of the control group and SP MS patients with reference ranges; all results are expressed as mean $\pm \mathrm{SD}$.

\begin{tabular}{|c|c|c|c|}
\hline Clinical Characteristics & Reference Range & $\begin{array}{l}\text { Control Group } \\
\quad(n=55)\end{array}$ & $\begin{array}{l}\text { SP MS } \\
(n=55)\end{array}$ \\
\hline Age (years) & - & $48.7 \pm 12.2$ & $48.6 \pm 12.5$ \\
\hline Female (\%) & - & 58 & 60 \\
\hline $\operatorname{BMI}\left(\mathrm{kg} / \mathrm{m}^{2}\right)$ & $18.5-24.9$ & $22.31 \pm 5.12$ & $21.1 \pm 9.7$ \\
\hline EDSS (0-10) & $0-10$ & NA & $5.5 \pm 1.8$ \\
\hline $\mathrm{BDI}(\leq 9)$ & $9-47$ & NA & $9.6 \pm 4.6$ \\
\hline Mean disease duration (years) & - & NA & $12.3 \pm 9.5$ \\
\hline $\mathrm{TG}(\mathrm{mg} / \mathrm{dL})$ & $35-150$ & $131.45 \pm 79.57$ & $73 \pm 61.27$ \\
\hline TChol (mg/dL) & $115-190$ & $189 \pm 44.20$ & $201 \pm 399.1$ \\
\hline $\mathrm{HDL}(\mathrm{mg} / \mathrm{dL})$ & $>45$ & $60.87 \pm 16.71$ & $72 \pm 20.4$ \\
\hline LDL (mg/dL) & $<70$ & $110.80 \pm 38.73$ & $90 \pm 41.5$ \\
\hline $\mathrm{LEU}\left(\times 10^{3} / \mu \mathrm{L}\right)$ & $4-10$ & $6.46 \pm 1.53$ & $5.15 \pm 2.4$ \\
\hline $\operatorname{RBC}\left(\times 10^{6} / \mu \mathrm{L}\right)$ & $3.80-5.40$ & $4.81 \pm 0.39$ & $4.41 \pm 0.7$ \\
\hline PLT $\left(\times 10^{3} / \mu \mathrm{L}\right)$ & $150-400$ & $258.89 \pm 68.10$ & $321.95 \pm 42.99$ \\
\hline GLU (mg/dL) & 70-99 & $96.69 \pm 26.07$ & $84.1 \pm 12$ \\
\hline $\mathrm{CR}(\mathrm{mg} / \mathrm{dL})$ & $0.50-0.90$ & $85.22 \pm 16.80$ & $72.4 \pm 13.4$ \\
\hline TSH (mIU/mL) & $0.27-4.20$ & $1.71 \pm 0.80$ & $1.6 \pm 0.9$ \\
\hline AST (IU/L) & $<32$ & $21.09 \pm 16.09$ & $26.7 \pm 14.07$ \\
\hline ALT (U/L) & $<33$ & $21.15 \pm 13.06$ & $28 \pm 12.4$ \\
\hline $\mathrm{PT}(\mathrm{sec})$ & $12-16$ & $12.28 \pm 2.29$ & $13.5 \pm 2.01$ \\
\hline INR (sec) & $0.91-1.31$ & $1.01 \pm 0.05$ & $1.5 \pm 0.04$ \\
\hline APTT (sec) & $26-40$ & $29.97 \pm 2.30$ & $31.2 \pm 1.45$ \\
\hline $\mathrm{FG}(\mathrm{mg} / \mathrm{dL})$ & $150-450$ & $316.94 \pm 58.92$ & $320.25 \pm 45.87$ \\
\hline ESR (mm/h) & $3-12$ & $9.35 \pm 8.90$ & $8.45 \pm 1.54$ \\
\hline CRP (mg/L) & $<5$ & $3.15 \pm 0.99$ & $12.5 \pm 5.5$ \\
\hline
\end{tabular}

Abbreviations: ALT—alanine aminotransferase; AST—aspartate aminotransferase; APTT—activated partial thromboplastin time; BDI—Beck's depression inventory; BMI—body mass index; $\mathrm{CR}$-creatinine; CRP-C reactive protein; EDSS — expanded disability status scale; ESR — erythrocyte sedimentation rate; FG—fibrinogen; GLU—glucose; HDL—high-density lipoprotein; LDL—low-density lipoprotein; LEU—leukocytes; RBC—red blood cells; PLT—platelets; PT—prothrombin time; TG—triglycerides; TChol—total cholesterol; TSH—thyroidstimulating hormone; INR—international normalized ratio; IU/L—international units per liter; mIU—milliinternational units per liter.

Control blood samples were collected from 55 healthy volunteers at the Laboratory Diagnostics Center in Lodz, Poland. The control group was matched by age (48.7 \pm 12.2$)$ and gender (female $n=32$; male $n=23$ ). Healthy volunteers were not taking any medications, and they had never been diagnosed with MS or other chronic diseases, coagulation disorders, neurological or hormonal illnesses, nor any chronic inflammatory diseases. Subjects enrolled into both groups did not receive any medicaments which could modulate platelet count or function, or influence platelet activation. Each of the healthy volunteers was subjected to screening (including hematological and biochemical tests) to confirm their medical condition. Clinical characteristics of the control group are included in Table 2. 
Author Contributions: Conceptualization, A.D., M.B. and J.S.-B.; data curation, A.D.; methodology, J.S.-B. and M.B.; formal analysis, A.D., J.S.-B. and M.B.; investigation, A.D. and M.B.; resources, E.M. and M.N.; writing-original draft preparation, A.D. and J.S.-B.; writing-review and editing, E.M., J.S.-B. and M.B.; supervision, M.B. and J.S.-B.; project administration, M.B. and J.S.-B.; funding acquisition, J.S.-B. and M.B. All authors have read and agreed to the published version of the manuscript.

Funding: This research was funded by the Polish National Science Centre, grant numbers UMO2016/21/B/NZ4/00543 and UMO-2018/31/B/NZ4/02688.

Institutional Review Board Statement: The study was conducted according to the guidelines of the Declaration of Helsinki, and approved by the Bioethics Committee of the University of Lodz, Poland with Resolution No. 15/KBBN-UŁ/II/2016 and No. 3/KBBN-UŁ/IV/2018. All participants gave their written informed consent before participation.

Informed Consent Statement: Informed consent was obtained from all subjects involved in the study.

Data Availability Statement: All data generated or analyzed during this study are included in this published article.

Conflicts of Interest: The authors declare no conflict of interest.

\section{References}

1. Rawish, E.; Nording, H.; Münte, T.; Langer, H.F. Platelets as Mediators of Neuroinflammation and Thrombosis. Front. Immunol. 2020, 11, 548631. [CrossRef]

2. Li, C.; Li, J.; Li, Y.; Lang, S.; Yougbare, I.; Zhu, G.; Chen, P.; Ni, H. Crosstalk between Platelets and the Immune System: Old Systems with New Discoveries. Adv. Hematol. 2012, 2012, 384685. [CrossRef]

3. Eisinger, F.; Patzelt, J.; Langer, H.F. The Platelet Response to Tissue Injury. Front. Med. 2018, 5, 317. [CrossRef]

4. Tomaiuolo, M.; Brass, L.F.; Stalker, T.J. Regulation of Platelet Activation and Coagulation and Its Role in Vascular Injury and Arterial Thrombosis. Interv. Cardiol. Clin. 2017, 6, 1-12. [CrossRef]

5. Li, N.; Hu, H.; Lindqvist, M.; Wikström-Jonsson, E.; Goodall, A.H.; Hjemdahl, P. Platelet-Leukocyte Cross Talk in Whole Blood Arter. Thromb. Vasc. Biol. 2000, 20, 2702-2708. [CrossRef] [PubMed]

6. Rainger, G.E.; Chimen, M.; Harrison, M.J.; Yates, C.M.; Harrison, P.; Watson, S.; Lordkipanidzé, M.; Nash, G.B. The role of platelets in the recruitment of leukocytes during vascular disease. Platelets 2015, 26, 507-520. [CrossRef] [PubMed]

7. Rossaint, J.; Margraf, A.; Zarbock, A. Role of Platelets in Leukocyte Recruitment and Resolution of Inflammation. Front. Immunol. 2018, 9, 2712. [CrossRef] [PubMed]

8. Lisman, T. Platelet-neutrophil interactions as drivers of inflammatory and thrombotic disease. Cell Tissue Res. 2018, 371, 567-576. [CrossRef] [PubMed]

9. Rossaint, J.; Zarbock, A. Platelets in leucocyte recruitment and function. Cardiovasc. Res. 2015, 107, 386-395. [CrossRef]

10. Minagar, A.; Alexander, J.S. Blood-brain barrier disruption in multiple sclerosis. Mult. Scler. J. 2003, 9, 540-549. [CrossRef] [PubMed]

11. Huang, W.-J.; Chen, W.-W.; Zhang, X. Multiple sclerosis: Pathology, diagnosis and treatments. Exp. Ther. Med. 2017, 13, 3163-3166. [CrossRef] [PubMed]

12. Dobson, R.; Giovannoni, G. Multiple sclerosis-A review. Eur. J. Neurol. 2019, 26, 27-40. [CrossRef]

13. Ciabattoni, G.; Porreca, E.; Di Febbo, C.; Di Iorio, A.; Paganelli, R.; Bucciarelli, T.; Pescara, L.; Del Re, L.; Giusti, C.; Falco, A.; et al. Determinants of platelet activation in Alzheimer's disease. Neurobiol. Aging 2007, 28, 336-342. [CrossRef] [PubMed]

14. Denis, H.L.; Lamontagne-Proulx, J.; St-Amour, I.; Mason, S.L.; Rowley, J.W.; Cloutier, N.; Tremblay, M.-E.; Vincent, A.T.; Gould, P.V.; Chouinard, S.; et al. Platelet abnormalities in Huntington's disease. J. Neurol. Neurosurg. Psychiatry 2018, 90, 272-283. [CrossRef]

15. Shrivastava, M.; Das, T.K.; Behari, M.; Pati, U.; Vivekanandhan, S. Ultrastructural Variations in Platelets and Platelet Mitochondria: A Novel Feature in Amyotrophic Lateral Sclerosis. Ultrastruct. Pathol. 2011, 35, 52-59. [CrossRef]

16. A Sheremata, W.; Jy, W.; Horstman, L.L.; Ahn, Y.S.; Alexander, J.S.; Minagar, A. Evidence of platelet activation in multiple sclerosis. J. Neuroinflamm. 2008, 5, 27. [CrossRef]

17. Bidot, C.J.; Horstman, L.L.; Jy, W.; Jimenez, J.J.; Ahn, Y.S.; Alexander, J.S.; Gonzalez-Toledo, E.; Kelley, R.E.; Minagar, A.; Bidot, C. Clinical and neuroimaging correlates of antiphospholipid antibodies in multiple sclerosis: A preliminary study. BMC Neurol. 2007, 7, 36. [CrossRef] [PubMed]

18. Spanevello, R.M.; Mazzanti, C.M.; Maldonado, P.A.; Zanin, R.; Morsch, A.; Hannel, L.; Mazzanti, A.; Festugatto, R.; Graça, D.; Schmatz, R.; et al. Activities of enzymes that hydrolyze adenine nucleotides in platelets from rats experimentally demyelinated with ethidium bromide and treated with interferon- $\beta$. Life Sci. 2007, 80, 1109-1114. [CrossRef]

19. Klineova, S.; Lublin, F.D. Clinical Course of Multiple Sclerosis. Cold Spring Harb. Perspect. Med. 2018, 8, a028928. [CrossRef] 
20. Roshanisefat, H.; Bahmanyar, S.; Hillert, J.; Olsson, T.; Montgomery, S. Multiple sclerosis clinical course and cardiovascular disease risk-Swedish cohort study. Eur. J. Neurol. 2014, 21, 1353-1388. [CrossRef]

21. Moccia, M.; Lanzillo, R.; Palladino, R.; Maniscalco, G.T.; De Rosa, A.; Russo, C.; Massarelli, M.; Carotenuto, A.; Postiglione, E.; Caporale, O.; et al. The Framingham cardiovascular risk score in multiple sclerosis. Eur. J. Neurol. 2015, 22, 1176-1183. [CrossRef]

22. Cerda, F.P.; Gomez, M.V.S.; Matute, C. The link of inflammation and neurodegeneration in progressive multiple sclerosis. Mult. Scler. Demyelinating Disord. 2016, 1. [CrossRef]

23. Morel, A.; Rywaniak, J.; Bijak, M.; Miller, E.; Niwald, M.; Saluk, J. Flow cytometric analysis reveals the high levels of platelet activation parameters in circulation of multiple sclerosis patients. Mol. Cell. Biochem. 2017, 430, 69-80. [CrossRef]

24. Dziedzic, A.; Morel, A.; Miller, E.; Bijak, M.; Sliwinski, T.; Synowiec, E.; Ceremuga, M.; Saluk-Bijak, J. Oxidative Damage of Blood Platelets Correlates with the Degree of Psychophysical Disability in Secondary Progressive Multiple Sclerosis. Oxidative Med. Cell. Longev. 2020, 2020, 2868014. [CrossRef]

25. Dziedzic, A.; Miller, E.; Bijak, M.; Przyslo, L.; Saluk-Bijak, J. Increased Pro-Thrombotic Platelet Activity Associated with Thrombin/PAR1-Dependent Pathway Disorder in Patients with Secondary Progressive Multiple Sclerosis. Int. J. Mol. Sci. 2020, 21, 7722. [CrossRef] [PubMed]

26. Shankar, H.; Garcia, A.; Prabhakar, J.; Kim, S.; Kunapuli, S.P. P2Y12 receptor-mediated potentiation of thrombin-induced thromboxane A2 generation in platelets occurs through regulation of Erk1/2 activation. J. Thromb. Haemost. 2006, 4, 638-647. [CrossRef] [PubMed]

27. Rauch, B.H.; Rosenkranz, A.C.; Ermler, S.; Böhm, A.; Driessen, J.; Fischer, J.W.; Sugidachi, A.; Jakubowski, J.A.; Schrör, K. Regulation of Functionally Active P2Y12 ADP Receptors by Thrombin in Human Smooth Muscle Cells and the Presence of P2Y12 in Carotid Artery Lesions*. Arter. Thromb. Vasc. Biol. 2010, 30, 2434-2442. [CrossRef]

28. Woulfe, D.; Yang, J.; Brass, L. ADP and platelets: The end of the beginning. J. Clin. Investig. 2001, 107, 1503-1505. [CrossRef]

29. Bagai, A.; Wang, T.Y.; Goodman, S.G.; Fisher, H.N.; Welsh, R.C.; Dery, J.-P.; Zhang, X.; Zhu, Y.E.; Cheema, A.N.; Dehghani, P.; et al. Longitudinal treatment patterns with ADP receptor inhibitors after myocardial infarction: Insights from the Canadian Observational AntiPlatelet sTudy. Int. J. Cardiol. 2017, 228, 459-464. [CrossRef]

30. Offermanns, S. Activation of Platelet Function Through G Protein-Coupled Receptors. Circ. Res. 2006, 99, 1293-1304. [CrossRef] [PubMed]

31. Harizi, H.; Corcuff, J.-B.; Gualde, N. Arachidonic-acid-derived eicosanoids: Roles in biology and immunopathology. Trends Mol. Med. 2008, 14, 461-469. [CrossRef]

32. Yagami, T.; Koma, H.; Yamamoto, Y. Pathophysiological Roles of Cyclooxygenases and Prostaglandins in the Central Nervous System. Mol. Neurobiol. 2016, 53, 4754-4771. [CrossRef] [PubMed]

33. Marjan, M.N.; Hamzeh, M.T.; Rahman, E.; Sadeq, V. A computational prospect to aspirin side effects: Aspirin and COX-1 interaction analysis based on non-synonymous SNPs. Comput. Biol. Chem. 2014, 51, 57-62. [CrossRef]

34. Zeiler, T.; Gritzka, D.; Karger, R.; Kretschmer, V. The effect of ASA on platelet activation during apheresis and on in-vitro properties of stored platelet concentrates. Transfusion 2004, 44, 1300-1305. [CrossRef] [PubMed]

35. Patrono, C.; Rocca, B. The future of antiplatelet therapy in cardiovascular disease. Annu. Rev. Med. 2010, 61, 49-61. [CrossRef]

36. Cowley, M.J.; Kuritzky, L. Developments in antiplatelet therapy for acute coronary syndromes and considerations for long-term management. Curr. Med. Res. Opin. 2009, 25, 1477-1490. [CrossRef]

37. Tang, X.-F.; Fan, J.-Y.; Meng, J.; Jin, C.; Yuan, J.-Q.; Yang, Y.-J. Impact of new oral or intravenous P2Y12 inhibitors and clopidogrel on major ischemic and bleeding events in patients with coronary artery disease: A meta-analysis of randomized trials. Atherosclerosis 2014, 233, 568-578. [CrossRef]

38. Horstman, L.L. Platelet microparticles: A wide-angle perspective. Crit. Rev. Oncol. 1999, 30, 111-142. [CrossRef]

39. Ohlmann, P.; Lecchi, A.; El-Tayeb, A.; Müller, C.E.; Cattaneo, M.; Gachet, C. The platelet P2Y12 receptor under normal and pathological conditions. Assessment with the radiolabeled selective antagonist [3H]PSB-0413. Purinergic Signal. 2012, 9, 59-66. [CrossRef]

40. Gachet, C. P2Y12 receptors in platelets and other hematopoietic and non-hematopoietic cells. Purinergic Signal. 2012 , 8, 609-619. [CrossRef]

41. Zhang, Y.; Zhang, S.; Ding, Z. Role of P2Y12 Receptor in Thrombosis. Adv. Exp. Med. Biol. 2016, 906, 307-324. [CrossRef]

42. Storey, R.; Sanderson, H.M.; White, A.E.; May, J.A.; Cameron, K.E.; Heptinstall, S. The central role of the P 2T receptor in amplification of human platelet activation, aggregation, secretion and procoagulant activity. Br. J. Haematol. 2000, 110, 925-934. [CrossRef] [PubMed]

43. Dorsam, R.T.; Kunapuli, S.P. Central role of the P2Y12 receptor in platelet activation. J. Clin. Investig. 2004, 113, 340-345. [CrossRef] [PubMed]

44. Wallentin, L. P2Y12 inhibitors: Differences in properties and mechanisms of action and potential consequences for clinical use. Eur. Heart J. 2009, 30, 1964-1977. [CrossRef]

45. André, P.; Delaney, S.M.; LaRocca, T.; Vincent, D.; DeGuzman, F.; Jurek, M.; Koller, B.; Phillips, D.R.; Conley, P.B. P2Y12 regulates platelet adhesion/activation, thrombus growth, and thrombus stability in injured arteries. J. Clin. Investig. 2003, 112, 398-406. [CrossRef]

46. Wu, C.-C.; Wu, S.-Y.; Liao, C.-Y.; Teng, C.-M.; Wu, Y.-C.; Kuo, S.-C. The roles and mechanisms of PAR4 and P2Y12/phosphatidylinositol 3-kinase pathway in maintaining thrombin-induced platelet aggregation. Br. J. Pharmacol. 2010, 161, 643-658. [CrossRef] 
47. Kim, S.; Foster, C.; Lecchi, A.; Quinton, T.M.; Prosser, D.M.; Jin, J.; Cattaneo, M.; Kunapuli, S.P. Protease-activated receptors 1 and 4 do not stimulate Gi signaling pathways in the absence of secreted ADP and cause human platelet aggregation independently of Gisignaling. Blood 2002, 99, 3629-3636. [CrossRef] [PubMed]

48. Smith, T.H.; Li, J.G.; Dores, M.R.; Trejo, J. Protease-activated receptor-4 and purinergic receptor P2Y12 dimerize, co-internalize, and activate Akt signaling via endosomal recruitment of $\beta$-arrestin. J. Biol. Chem. 2017, 292, 13867-13878. [CrossRef]

49. Khan, A.; Li, D.; Ibrahim, S.; Smyth, E.; Woulfe, D.S. The Physical Association of the P2Y12 Receptor with PAR4 Regulates Arrestin-Mediated Akt Activation. Mol. Pharmacol. 2014, 86, 1-11. [CrossRef]

50. Persson, R.; Lee, S.; Yood, M.U.; Wagner, M.; Minton, N.; Niemcryk, S.; Lindholm, A.; Evans, A.; Jick, S. Incident cardiovascular disease in patients diagnosed with multiple sclerosis: A multi-database study. Mult. Scler. Relat. Disord. 2020, $37,101423$. [CrossRef]

51. Mincu, R.I.; Magda, L.S.; Florescu, M.; Velcea, A.; Mihaila, S.; Mihalcea, D.; Popescu, B.O.; Chiru, A.; Tiu, C.; Cinteza, M.; et al. Cardiovascular Dysfunction in Multiple Sclerosis. MAEDICA J. Clin. Med. 2015, 10, 364-370.

52. Morel, A.; Bijak, M.; Miller, E.; Rywaniak, J.; Miller, S.; Saluk, J. Relationship between the Increased Haemostatic Properties of Blood Platelets and Oxidative Stress Level in Multiple Sclerosis Patients with the Secondary Progressive Stage. Oxid. Med. Cell. Longev. 2015, 2015, 240918. [CrossRef]

53. Morel, A.; Miller, E.; Bijak, M.; Saluk, J. The increased level of COX-dependent arachidonic acid metabolism in blood platelets from secondary progressive multiple sclerosis patients. Mol. Cell. Biochem. 2016, 420, 85-94. [CrossRef]

54. Wang, B.; Wu, L.; Chen, J.; Dong, L.; Chen, C.; Wen, Z.; Hu, J.; Fleming, I.; Wang, D.W. Metabolism pathways of arachidonic acids: Mechanisms and potential therapeutic targets. Signal Transduct. Target. Ther. 2021, 6, 1-30. [CrossRef]

55. Giacomazzi, A.; Degan, M.; Calabria, S.; Meneguzzi, A.; Minuz, P. Antiplatelet Agents Inhibit the Generation of Platelet-Derived Microparticles. Front. Pharmacol. 2016, 7, 314. [CrossRef] [PubMed]

56. Takano, K.; Asazuma, N.; Satoh, K.; Yatomi, Y.; Ozaki, Y. Collagen-induced generation of platelet-derived microparticles in whole blood is dependent on ADP released from red blood cells and calcium ions. Platelets 2004, 15, 223-229. [CrossRef]

57. Buckland, R.; Sugidachi, A.; A Jakubowski, J.; Storey, R.; Judge, H.M. Relationship between degree of P2Y12 receptor blockade and inhibition of P2Y12-mediated platelet function. Thromb. Haemost. 2010, 103, 1210-1217. [CrossRef] [PubMed]

58. Behan, M.W.H.; Fox, S.C.; Heptinstall, S.; Storey, R. Inhibitory effects of P2Y12receptor antagonists on TRAP-induced platelet aggregation, procoagulant activity, microparticle formation and intracellular calcium responses in patients with acute coronary syndromes. Platelets 2005, 16, 73-80. [CrossRef]

59. Simak, J.; Gelderman, M.P.; Yu, H.; Wright, V.; Baird, A.E. Circulating endothelial microparticles in acute ischemic stroke: A link to severity, lesion volume and outcome. J. Thromb. Haemost. 2006, 4, 1296-1302. [CrossRef]

60. Wang, J.; Huang, Y.-J.; Wang, Y.; Xu, M.-G.; Wang, L.; Wang, S.; Tao, J. Increased Circulating CD31+/CD42- Microparticles Are Associated With Impaired Systemic Artery Elasticity in Healthy Subjects. Am. J. Hypertens. 2007, 20, 957-964. [CrossRef]

61. Lacroix, R.; Dubois, C.; Leroyer, A.; Sabatier, F.; Dignat-George, F. Revisited role of microparticles in arterial and venous thrombosis. J. Thromb. Haemost. 2013, 11, 24-35. [CrossRef]

62. Italiano, J.E.; Mairuhu, A.T.A.; Flaumenhaft, R. Clinical relevance of microparticles from platelets and megakaryocytes. Curr. Opin. Hematol. 2010, 17, 578-584. [CrossRef]

63. Gros, A.; Ollivier, V.; Ho-Tin-Noã, B. Platelets in Inflammation: Regulation of Leukocyte Activities and Vascular Repair. Front. Immunol. 2015, 5, 678. [CrossRef]

64. Manne, B.K.; Xiang, S.C.; Rondina, M.T. Platelet secretion in inflammatory and infectious diseases. Platelets 2017, $28,155-164$. [CrossRef]

65. Wagner, D.D.; Burger, P.C. Platelets in Inflammation and Thrombosis. Arter. Thromb. Vasc. Biol. 2003, 23, 2131-2137. [CrossRef]

66. Gawaz, M.; Langer, H.; May, A.E. Platelets in inflammation and atherogenesis. J. Clin. Investig. 2005, 115, 3378-3384. [CrossRef]

67. Golebiewska, E.M.; Poole, A.W. Platelet secretion: From haemostasis to wound healing and beyond. Blood Rev. 2015, 29, 153-162. [CrossRef]

68. Sharda, A.; Flaumenhaft, R. The life cycle of platelet granules. F1000Research 2018, 7, 236. [CrossRef]

69. Furie, B.; Furie, B.C. Role of platelet P-selectin and microparticle PSGL-1 in thrombus formation. Trends Mol. Med. 2004, 10, 171-178. [CrossRef] [PubMed]

70. Kuenz, B.; Lutterotti, A.; Khalil, M.; Ehling, R.; Gneiss, C.; Deisenhammer, F.; Reindl, M.; Berger, T. Plasma levels of soluble adhesion molecules sPECAM-1, sP-selectin and sE-selectin are associated with relapsing-remitting disease course of multiple sclerosis. J. Neuroimmunol. 2005, 167, 143-149. [CrossRef]

71. Lam, F.W.; Vijayan, K.V.; Rumbaut, R.E. Platelets and Their Interactions with Other Immune Cells. Compr. Physiol. 2015, 5, 1265-1280. [CrossRef] [PubMed]

72. Dixon, D.A.; Tolley, N.D.; Bemis-Standoli, K.; Martinez, M.L.; Weyrich, A.S.; Morrow, J.D.; Prescott, S.M.; Zimmerman, G.A. Expression of COX-2 in platelet-monocyte interactions occurs via combinatorial regulation involving adhesion and cytokine signaling. J. Clin. Investig. 2006, 116, 2727-2738. [CrossRef] [PubMed]

73. Jonnalagadda, D.; Izu, L.T.; Whiteheart, S. Platelet secretion is kinetically heterogeneous in an agonist-responsive manner. Blood 2012, 120, 5209-5216. [CrossRef] [PubMed]

74. Leiter, O.; Walker, T.L. Platelets in Neurodegenerative Conditions-Friend or Foe? Front. Immunol. 2020, 11, 747. [CrossRef] 
75. Curvers, J.; De Wildt-Eggen, J.; Heeremans, J.; Scharenberg, J.; de Korte, D.; Van Der Meer, P.F. Flow cytometric measurement of CD62P (P-selectin) expression on platelets: A multicenter optimization and standardization effort. Transfusion 2008, 48, 1439-1446. [CrossRef]

76. Habets, K.L.; Trouw, L.A.; Levarht, E.N.; Korporaal, S.J.; Habets, P.A.; De Groot, P.; Huizinga, T.W.; Toes, R.E. Anti-citrullinated protein antibodies contribute to platelet activation in rheumatoid arthritis. Arthritis Res. Ther. 2015, 17, 209. [CrossRef]

77. Emoretti, R.; Epansiot, J.; Ebettati, D.; Estrazielle, N.; Ghersi-Egea, J.-F.; Edamante, G.; Efleiss, B.; Etitomanlio, L.; Egressens, P. Blood-brain barrier dysfunction in disorders of the developing brain. Front. Neurosci. 2015, 9, 40. [CrossRef]

78. Shin, J.-H.; Kwon, H.-W.; Cho, H.-J.; Rhee, M.H.; Park, H.-J. Vasodilator-stimulated phosphoprotein-phosphorylation by ginsenoside Ro inhibits fibrinogen binding to $\alpha \mathrm{Ilb} / \beta 3$ in thrombin-induced human platelets. J. Ginseng Res. 2016, 40, 359-365. [CrossRef]

79. Rondina, M.T.; Weyrich, A.S. Regulation of the genetic code in megakaryocytes and platelets. J. Thromb. Haemost. 2015, 13, S26-S32. [CrossRef]

80. Rowley, J.W.; Schwertz, H.; Weyrich, A.S. Platelet mRNA. Curr. Opin. Hematol. 2012, 19, 385-391. [CrossRef]

81. Patel, S.R.; Hartwig, J.H.; Italiano, J.E. The biogenesis of platelets from megakaryocyte proplatelets. J. Clin. Investig. 2005, 115, 3348-3354. [CrossRef]

82. Mallouk, N.; Varvat, J.; Berger, A.; Epinat, M.; Accassat, S.; Garcin, A.; Montmartin, A.; Li, G.; Garnier, P.; Mismetti, P.; et al. Assessment of a flow cytometry technique for studying signaling pathways in platelets: Monitoring of VASP phosphorylation in clinical samples. Pr. Lab. Med. 2018, 11, 10-18. [CrossRef] [PubMed]

83. Schwarz, U.R.; Geiger, J.; Walter, U.; Eigenthaler, M. Flow cytometry analysis of intracellular VASP phosphorylation for the assessment of activating and inhibitory signal transduction pathways in human platelets-Definition and detection of ticlopidine/clopidogrel effects. Thromb. Haemost. 1999, 82, 1145-1152. [CrossRef] [PubMed]

84. Walkowiak, B.; Michalak, E.; Koziolkiewicz, W.; Cierniewski, C.S. Rapid photometric method for estimation of platelet count in blood plasma or platelet suspension. Thromb. Res. 1989, 56, 763-766. [CrossRef]

85. Polman, C.H.; Reingold, S.C.; Banwell, B.; Clanet, M.; Cohen, J.A.; Filippi, M.; Fujihara, K.; Havrdova, E.K.; Hutchinson, M.; Kappos, L.; et al. Diagnostic criteria for multiple sclerosis: 2010 Revisions to the McDonald criteria. Ann. Neurol. 2011, 69, $292-302$. [CrossRef] [PubMed]

86. Lublin, F.D.; Reingold, S.C. Defining the clinical course of multiple sclerosis: Results of an international survey. National Multiple Sclerosis Society (USA) Advisory Committee on Clinical Trials of New Agents in Multiple Sclerosis. Neurology 1996, 46, 907-911. [CrossRef] [PubMed]

87. Kurtzke, J.F. Rating neurologic impairment in multiple sclerosis: An expanded disability status scale (EDSS). Neurology 1983, 33, 1444. [CrossRef] [PubMed]

88. Beck, A.T.; Steer, R.A.; Ball, R.; Ranieri, W.F. Comparison of Beck Depression Inventories-IA and-II in Psychiatric Outpatients. J. Pers. Assess. 1996, 67, 588-597. [CrossRef] [PubMed] 